\title{
UN DERECHO JURISPRUDENCIAL. LA PROPIEDAD COLECTIVA Y LA CORTE INTERAMERICANA*
}

\author{
SEBASTIÁN LÓPEZ ESCARCENA**
}

RESUMEN: Son trece las sentencias condenatorias dictadas a la fecha por la Corte Interamericana de Derechos Humanos, por incumplimiento de los derechos comunales que el artículo 21 del Pacto de San José de Costa Rica le reconoce a los pueblos indígenas y tribales. Han pasado catorce ańos desde que se fallara la primera de estas decisiones judiciales. Es de presumir que a Nicaragua, Guatemala, Surinam, Paraguay, Ecuador, Colombia, Panamá y Honduras se les van a unir otros estados, también parte de la Convención Americana sobre Derechos Humanos, por violar los derechos colectivos que protege esta disposición convencional, uno de los cuales es el de propiedad indígena y tribal. Estos derechos han sido elaborados a partir de una interpretación evolutiva y pro homine, donde el diálogo judicial y la coordinación con el derecho internacional extra interamericano y el derecho comparado juegan un papel central. El debido respeto de estos derechos requiere conocer bien la jurisprudencia judicial de donde emanan. Este trabajo ofrece una sistematización de las obligaciones internacionales que establece el artículo 21 del mencionado tratado, y de los principios jurídicos que las fundamentan, con el fin de favorecer el cumplimiento de una disposición bastante más compleja de lo que su simple lectura permite anticipar.

PALABRAS CLAVE: Derechos humanos - propiedad - pueblos indígenas y tribales - Corte Interamericana

\footnotetext{
* Fecha de recepción: 15 de marzo de 2016.

Fecha de aceptación: 19 de mayo de 2016.

Este trabajo es parte del proyecto Fondecyt Regular $N^{\circ} 11113065$, adjudicado el 2012 y titulado "La constitucionalización de la propiedad indígena y su coordinación con otras formas de propiedad".

** Profesor asociado de la Facultad de Derecho de la Pontificia Universidad Católica de Chile, e investigador asociado (associate fellow/membre associé) del Centro para el Estudio de la Gobernanza Global de la Universidad Católica de Lovaina, Bélgica, y del Instituto de Investigación en Derecho Internacional y Europeo de la Universidad París 1 "PanthéonSorbonne", Francia. PhD (Edimburgo), LLM (Leiden), Abogado y Licenciado en Derecho (Católica de Chile). Correo electrónico: rlopeze@uc.cl
} 


\title{
A JURISPRUDENTIAL RIGHT. COLLECTIVE PROPERTY AND THE INTER-AMERICAN COURT
}

\begin{abstract}
Thirteen guilty verdicts have been issued to this date by the Inter-American Court of Human Rights for infringements of the communal rights that Article 21 of the Pact of San José de Costa Rica recognises to indigenous and tribal people. Fourteen years have passed since the first of these judicial decisions was issued. It is presumable that other states party to the American Convention on Human Rights will join Nicaragua, Guatemala, Surinam, Paraguay, Ecuador, Colombia, Panamá and Honduras for violating the collective rights that this conventional provision protects, one of which is indigenous and tribal property. These rights derive from an evolutive and pro homine interpretation, where judicial dialogue and the coordination with extra Inter-American international law and comparative law play a leading role. Due respect for these rights require that the case-law from where they arise is well-known. This work offers a systematisation of the international obligations that Article 21 of the mentioned treaty establishes, and of the legal principles that constitute their basis, to aid in the fulfilment of a provision, which is far more complex than what a simple reading of it allows to anticipate.
\end{abstract}

KEY WORDS: Human rights - property - indigenous and tribal people - Inter-American Court.

Sumario: Introducción; 1) La propiedad colectiva en la Convención Americana; 2) Pueblos indigenas y también tribales; 3) Sentencias que confirman una tendencia; 4) Salvaguardando la subsistencia de un pueblo; 5) El derecho de consulta y el artículo 21; 6) Awas Tingni, Moiwanay y Cía.; Conclusión; Bibliografía citada; Instrumentos citados; Jurisprudencia citada.

\section{INTRODUCCIÓN}

En Pueblos Kaliña y Lokono (2015), la Corte Interamericana de Derechos Humanos condenó a Surinam por violar el derecho de propiedad colectiva indígena y tribal protegido por el artículo 21 del Pacto de San José de Costa Rica ${ }^{1}$. Esta es la última sentencia de una ya copiosa jurispruden-

Ver en general Corte Interamericana de Derechos Humanos. 25 de noviembre de 2015. Serie C No. 309 (sentencia). "Pueblos Kaliña y Lokono c. Surinam”. 
cia que comenzó con Comunidad Mayagna (Sumo) Awas Tingni (2001), casi trece ańos después que este tribunal internacional dictara su primera sentencia de fondo en un caso contencioso ${ }^{2}$. Para sorpresa de la comunidad indígena Mayagna o Sumo que presentó en 1995 la denuncia contra Nicaragua ante la Comisión Interamericana de Derechos Humanos, Awas Tingni se transformó en un precedente de enorme importancia para otros pueblos indígenas y tribales no solo de América Latina, sino del mundo entero $^{3}$. A partir de esta decisión judicial, la Corte ha ido desarrollando distintos criterios interpretativos que extienden la protección convencional a un tipo de propiedad no prevista originalmente en el Pacto de San José de Costa Rica ${ }^{4}$. Vale decir, ante el silencio de dicho tratado, el tribunal ha establecido y articulado ciertos derechos para los pueblos indígenas

Las sentencias de la Corte Interamericana están disponibles en

http://www.corteidh.or.cr/index.php/es/casos-contenciosos [visitado el 15/3/2015].

2 Ver en general Corte Interamericana de Derechos Humanos. 29 de julio de 1988. Serie C No. 4 (sentencia). "Manfredo Velásquez Rodríguez c. Honduras"; y Corte Interamericana de Derechos Humanos. 31 de agosto de 2001. Serie C No. 79 (sentencia). "Comunidad Mayagna (Sumo) Awas Tingni c. Nicaragua".

3 Ver Anaya, James, y Grossman, Claudio (2002) “The Case of Awas Tingni v. Nicaragua: A Step in the International Law of Indigenous Peoples". Arizona Journal of International and Comparative Law, Vol. 19, pp. 1-15, en p. 1.

Ver también Ostby, Anne (2003) “Will Foreign Investors Regulate Indigenous Peoples' Right to Self-Determination”. Wisconsin International Law Journal, Vol. 21 No 1, pp. 22350, en pp. 223, 230 y 232; Rodríguez-Piñero, Luis (2006) "El sistema interamericano de derechos humanos y los pueblos indígenas”. En Berraondo, Mikel (ed.): Pueblos indígenas y derechos humanos. Bilbao: Publicaciones de la Universidad de Deusto, pp. 153-203, en pp. 153, 164, 185, 201; Weckel, Philippe, y Rinaldi, Karine (2008) "Relativisme culturel ou universalité des droits de l'homme? La réponse donnée par la Cour Interaméricaine des Droits de l'Homme par la prise en compte des coutumes indiennes”. En Société FrançAIse pour le Droit international (ed.): Droit international et diversité des cultures juridiques / International Law and Diversity of Legal Cultures. París: Editions A. Pedone, pp. 421-31, en pp. 428-9; Rinaldi, Karine (2009) "Le droit des populations autochtones et tribales à la propriété dans le système interaméricain de protection des droits de l'homme". En Hennebel, Ludovic, y Tigroudja, Hélène (eds.): Le particularisme interaméricain des droits de l'homme: en l'honneur du 40e anniversaire de la Convention Américaine des Droits de l'Homme. París: Editions A. Pedone, 2009, pp. 215-50, en pp. 221, 233; Xanthaki, Alexandra (2009). "Indigenous Rights in International Law over the Last 10 Years and Future Developments”. Melbourne Journal of International Law, Vol. $10 \mathrm{~N}^{\circ}$ 1, pp. 27-37, en pp. 32-3; Del Toro, Mauricio (2010). "El derecho de propiedad colectiva de los miembros de comunidades y pueblos indígenas en la jurisprudencia de la Corte Interamericana de Derechos Humanos". Anuario Mexicano de Derecho Internacional, Vol. 10, pp. 49-95, en p. 59; Rodríguez-Piñero, Luis (2013): "La sentencia de la Corte Interamericana”. En GóMEz Isa, Felipe (ed.): El caso Awas Tingni. Derechos humanos entre lo local y lo global. Bilbao: Publicaciones de la Universidad de Deusto, pp. 123-38, en pp. 123-5; y Rodríguez-PiñeRO, Luis (2013): "El impacto internacional de la sentencia”. En Gómez IsA, Felipe (ed.): El caso Awas Tingni. Derechos humanos entre lo local y lo global. Bilbao: Publicaciones de la Universidad de Deusto, pp. 163-203, en pp. 163-9 y 201-3.

4 Ver Corte Interamericana de Derechos Humanos. 14 de octubre de 2014. Serie C No. 284 (voto parcialmente disidente del juez Ferrer Mac-Gregor). "Pueblos Indígenas Kuna de Madungandí y Emberá de Bayano y sus Miembros c. Panamá”, párrafos 11-2. 
y tribales en base a dos pilares: los principios de interpretación evolutiva y pro homine, por un lado, y los fenómenos de fertilización cruzada y diálogo judicial, por otro ${ }^{5}$. Estas últimas manifestaciones son comunes en el derecho internacional, por lo que no es algo que se restrinja al área de derechos humanos ${ }^{6}$. Y es que, en la práctica, la jurisprudencia internacional es mucho más que un simple medio auxiliar para la determinación de las

Ver también Rodríguez-Piñero (2006): "El sistema interamericano de derechos humanos...", pp. 159 y 186-7; Forero, Felipe (2010). "Conectividad: alcances del derecho a la propiedad aborigen y tribal en la jurisprudencia de la Corte Interamericana de Derechos Humanos". International Law - Revista Colombiana de Derecho Internacional, Vol. 16, pp. 177-211, en pp. 181-5; Rodríguez Garavito, César, y Morris, Megan (eds.) (2010): La consulta previa a pueblos indigenas: los estándares del derecho internacional. Bogotá: Ediciones Uniandes, 96 pp., en p. 45; RodríGuez-Piñero (2013): “La sentencia...”, p. 134; y Ruiz Chiriboga, Oswaldo, y Donoso, Gina (2014): "Pueblos indígenas y la Corte Interamericana de Derechos Humanos. Fondo y reparaciones". En Steiner, Christian, y Uribe, Patricia (eds.): Convención Americana sobre Derechos Humanos: comentario, La Paz: Fundación Konrad Adenauer, pp. 947-1026, en pp. 953 y 971.

Cf. Anaya, James, y Williams, Robert (2001). “The Protection of Indigenous Peoples' Rights over Lands and Natural Resources under the Inter-American Human Rights System". Harvard Human Rights Journal, Vol. 14, pp. 33-86, en p. 41; y Rinaldi (2009): "Le droit des populations autochtones et tribales...”, pp. 216-7, 219-21 y 247-8.

5 Sobre los principios de interpretación evolutiva y más favorable a la persona, ver AnAYA y Williams (2001). “The Protection of Indigenous Peoples' Rights...”, pp. 41-2; RodríguezPiñero (2006): "El sistema interamericano de derechos humanos...", pp. 1886-7; WeCKel y Rinaldi (2008): "Relativisme culturel ou universalité... pp. 423-4; López-Murcia, Julián, y Maldonado, Gabriela (2009). "La Protección de la Propiedad de la Tierra en la Jurisprudencia de la Corte Interamericana de Derechos Humanos y su Aplicación al Caso de las Comunidades Campesinas en Colombia". International Law: Revista Colombiana de Derecho Internacional, Vol. 14, pp.71-105, en p. 78; Rinaldi (2009): "Le droit des populations autochtones et tribales...", pp. 219-20 y 226-8; Forero (2010). "Conectividad: alcances del derecho a la propiedad...", pp. 181-5; Rodríguez-Piñero (2013): "La sentencia...”, pp. 128-31; Ramos, André de Carvalho (2014): Curso de direitos humanos. São Paulo: Editora Saraiva, 656 pp., en pp. 100-9; y Ramos, André de Carvalho (2014): Teoria geral dos direitos humanos na ordem internacional. São Pablo: Editora Saraiva, 343 pp., en pp. 103-15.

Ver también Nash, Claudio (2013): "El principio pro persona en la jurisprudencia de la Corte Interamericana de Derechos Humanos". En Nogueira, Humberto (ed.) (2013): Diálogo judicial multinivel y principios interpretativos favor persona $y$ de proporcionalidad. Santiago: Librotecnia, pp. 155-99; BJorge, Eirik (2014): The Evolutionary Interpretation of Treaties. Oxford: Oxford University Press, 240 pp.; Rodríguez, Gabriela (2014): "Artículo 29. Normas de interpretación”. En SteIner, Christian, y URIBe, Patricia (eds.): Convención Americana sobre Derechos Humanos: comentario. La Paz: Fundación Konrad Adenauer, pp. 706-14; y Mazzuoli, Valerio de Oliveira, y Ribeiro, Dilton (2016). "The Pro Homine Principle as an Enshrined Feature of International Human Rights Law”. Indonesian Journal of International \& Comparative Law, Vol. $3 \mathrm{~N}^{\circ} 1$, pp. 77-99.

6 Ver e.g. Linderfalk, Ulf (2015). "Cross-Fertilisation in International Law”. Nordic Journal of International Law, Vol. $84 \mathrm{~N}^{\circ} 3$, pp. 428-55.

Respecto del derecho internacional de los derechos humanos, ver Rodríguez Garavito y Morris (eds.) (2010): La consulta previa..., p. 45; Pentassuglia, Gaetano (2011). "Towards a Jurisprudential Articulation of Indigenous Land Rights". European Journal of International Law, Vol. $22 \mathrm{~N}^{\circ}$ 1, pp. 165-202, en pp. 180-2, 190 y 199-202; y RodríGuezPiñero (2013): “El impacto internacional...”, pp. 197-200. 
reglas de derecho regido por el principio del efecto relativo de las sentencias, como usualmente se la cataloga ${ }^{7}$. Tienen tal importancia las decisiones judiciales para el desarrollo del derecho internacional, que parte de la doctrina ya habla de un sistema de precedente de facto o blando. Esto quiere decir que, sin llegar a conformarse al principio del stare decisis, las resoluciones de los tribunales internacionales constituyen argumentos de autoridad que difícilmente pueden ser desestimados con posterioridad. Es a través de la interpretación de la normativa aplicable que la jurisprudencia de estos tribunales influye, de manera decisiva, en la evolución ius internacional ${ }^{8}$. Los derechos de naturaleza comunal o colectiva de los pueblos indígenas y tribales son justamente un buen ejemplo de lo anterior -uno particularmente acusado, pues implican ciertas obligaciones

Ver en general Nogueira, Humberto (ed.) (2012): El diálogo transjudicial de los tribunales constitucionales entre sí y con las cortes internacionales de derechos humanos. Santiago: Librotecnia, 525 pp.; Burgorgue-Larsen, Laurence (2013): El diálogo judicial. Máximo desafio de los tiempos jurídicos modernos. México, D.F.: Editorial Porrúa, 315 pp.; Ferrer, Eduardo, y Herrera, Alfonso (eds.) (2013): Diálogo jurisprudencial en derechos humanos: entre tribunales constitucionales y cortes internacionales. Valencia: Editorial Tirant lo Blanch, 1412 pp.; NogueIra, Humberto (ed.) (2013): Diálogo judicial multinivel y principios interpretativos favor persona y de proporcionalidad. Santiago: Librotecnia, 339 pp.; Aguilar, Gonzalo (ed.) 2014): Diálogo entre jurisdicciones: el desarrollo del derecho público y una nueva forma de razonar. Santiago: Librotecnia, 493 pp.; y NogueIRa, Humberto (ed.) (2014): La protección de los derechos humanos y fundamentales de acuerdo a la Constitución y el derecho internacional de los derechos humanos. Santiago: Librotecnia, $492 \mathrm{pp}$.

$7 \quad$ Ver arts. 38 y 59 del Estatuto de la Corte Internacional de Justicia de 1945, disponible en http://www.icj-cij.org/homepage/sp/icjstatute.php [visitado el 15/3/2015].

Ver también Thirlway, Hugh (2014): The Sources of International Law. Nueva York: Oxford University Press, 239 pp., en 117-8.

Ver en general Shahabuddeen, Mohamed (2007): Precedent in the World Court. Nueva York: Cambridge University Press, 268 pp.; Shany, Yuval (2009). "No Longer a Weak Department of Power? Reflections on the Emergence of a New International Judiciary". European Journal of International Law, Vol. $20 \mathrm{~N}^{\circ}$ 1, pp. 73-91; JАСОВ, Marc (2011). "Precedents: Lawmaking through International Adjudication". German Law Journal, Vol. 12 N$^{\circ}$ 5, pp. 1005-32; von Bogdandy, Armin y Venzke, Ingo (2011). "Beyond Dispute: International Judicial Institutions as Lawmakers". German Law Journal, Vol. 12 № 5, pp. 979-1003; Venzke, Ingo (2012). "Role of International Courts as Interpreters and Developers of the Law: Working out the Jurisgenerative Practice of Interpretation". Loyola of Los Angeles International and Comparative Law Review, Vol. $34 \mathrm{~N}^{\circ}$ 1, pp. 99-131; y VenzKe, Ingo (2014): How Interpretation Makes International Law: On Semantic Change And Normative Twists. Oxford: Oxford University Press, 344 pp.

8 Para el caso del derecho internacional de la inversión ver e.g. López Escarcena, Sebastián (2014): Indirect Expropriation in International Law. Cheltenham: Edward Elgar Publishing, 254 pp., en 186-7.

Ver en general Commission, Jeffery (2007). "Precedent in Investment Treaty Arbitration. A Citation Analysis of a Developing Jurisprudence". Journal of International Arbitration, Vol. $24 \mathrm{~N}^{\circ}$ 2, pp. 129-58; y Paulsson, Jan (2010): "The Role of Precedent in Investment Arbitration”. En Yannaca-Small, Katia (ed.): Arbitration under International Investment Agreements: A Guide to the Key Issues. Nueva York: Oxford University Press, pp. 699-718. 
internacionales para los estados parte de la Convención Americana que favorecen, en no pocos casos, a un número importante de sus nacionales?

Tanto en Awas Tingni como en Kaliña y Lokono, Nicaragua y Surinam incumplieron el artículo 21 al no haber delimitado y demarcado las tierras de las comunidades indígenas respectivas ni haber otorgado los títulos de propiedad correspondientes, sobre las cuales el estado respectivo otorgó concesiones de explotación a terceros. Los hechos de cada caso y los catorce años de jurisprudencia interamericana sobre propiedad, identidad y participación indígena y tribal explican que en Kaliña y Lokono se agregaran a los incumplimientos estatales ya presentes en Awas Tingni, la falta de consulta y de un estudio de impacto ambiental y social. Si bien estos casos sirven para ilustrar situaciones constitutivas de violaciones al artículo 21, solo el estudio sistemático de la jurisprudencia de la Corte sobre propiedad indígena y tribal permite identificar las obligaciones internacionales que ha ido reconociendo en este ámbito, así como los principios jurídicos sobre los cuales descansan. No hay duda de que la protección convencional de los pueblos indígenas y tribales es una particularidad del sistema interamericano de derechos humanos ${ }^{10}$. Los estados parte del Pacto de San José de Costa Rica requieren tener claridad sobre dichas obligaciones y principios, a fin de poder ajustar su normativa y su comportamiento a las exigencias de este tribunal. El presente trabajo tiene por objeto facilitar, en la medida de lo posible, el cumplimiento del conjunto de obligaciones y principios jurisprudenciales que desde el 2001 viene elaborando este tribunal internacional a partir de lo dispuesto en el

$9 \quad$ Hay diversos cálculos al respecto.

Ver e.g. Thornberry, Patrick (2002): Indigenous Peoples and Human Rights. Manchester: Manchester University Press, 484 pp., en pp. 15-8; Hannum, Hurst (2003): "Indigenous Rights". En Lyons, Gene, y Mayall, James (eds): International Human Rights in the 21st Century: Protecting the Rights of Groups, pp. 72-99, en p. 72; ECLAC (2005): The Millennium Development Goals: A Latin American and Caribbean Perspective. Santiago: Publicaciones de la ONU, 321 pp., en p. 48-9; Dhommeaux, Jean (2009): "Les communautés autochtones et tribales dans la jurisprudence de la Cour Interaméricaine des Droits de l'Homme”. En Hennebel, Ludovic, y Tigroudja, Hélène (eds.): Le particularisme interaméricain des droits de l'homme: en l'honneur du 40e anniversaire de la Convention Américaine des Droits de l'Homme. París: Editions A. Pedone, pp. 181-213, en p. 184; Rinaldi (2009): "Le droit des populations autochtones et tribales...", p. 217; Sieder, Rachel (2011): "Pueblos indígenas y derecho(s) en América Latina”. En Rodríguez Garavito, César, (ed.), El derecho en América Latina: un mapa para el pensamiento jurídico del siglo XXI. Buenos Aires: Siglo Veintiuno Editores, pp. 303-21, en pp. 303-6; y Schettini, Andrea (2012). "Por un nuevo paradigma de protección de los derechos de los pueblos indígenas: un análisis crítico de los parámetros establecidos por la Corte Interamericana de Derechos Humanos". Sur Revista Internacional de Derechos Humanos, Vol. 17, pp. 65-87, en pp. 65-6.

10 Sobre la situación jurídica de estos pueblos en Europa, a nivel regional, ver e.g. EIDE (2006). "Rights of Indigenous Peoples - Achievements in International Law during the Last Quarter of a Century". Netherlands Yearbook of International Law, Vol. 37, pp. 155-212, en pp. 177-9. 
artículo 21. Solo conociendo y entendiendo este precepto, tal como ha sido interpretado desde Awas Tingni hasta Kaliña y Lokono, podrán los estados parte de la Convención Americana sobre Derechos Humanos proteger adecuadamente los derechos colectivos ahí reconocidos.

\section{1) LA PROPIEDAD COLECTIVA EN LA CONVENCIÓN AMERICANA}

El primer canon de derechos reconocidos por el sistema interamericano incluyó en su listado a la propiedad. Conforme al artículo XXIII de la Declaración Americana de Derechos y Deberes del Hombre, adoptada en la Novena Conferencia Internacional Americana de 1948, toda persona tiene este derecho ${ }^{11}$. Dos décadas después, el segundo catálogo del sistema interamericano volvió a mencionar a la propiedad entre los derechos reconocidos. De acuerdo al artículo 21 de la Convención Americana sobre Derechos Humanos de 1969, la ley puede subordinar el uso y el goce de la propiedad al interés social, pero no puede privar a una persona de sus bienes sin que la medida expropiatoria haya sido adoptada por razones de utilidad pública y vaya acompañada de una indemnización justa, en las casos y la forma que establezca la ley ${ }^{12}$. Si bien este artículo se titula "Derecho a la propiedad privada", su texto también protege el derecho de propiedad $^{13}$. La jurisprudencia de la Corte no ha distinguido entre ambos derechos al aplicar esta disposición. Ivcher Bronstein (2001) fue el primer caso fallado por la Corte Interamericana en que el estado demandado fue condenado por violar el derecho de propiedad privada protegido en el artículo $21^{14}$. Ese mismo año, el tribunal dictó sentencia en otra controversia en la que condenó al estado demandado por incumplir esta

11 La Declaración Americana de Derechos y Deberes del Hombre está disponible en

http://www.oas.org/es/cidh/mandato/Basicos/declaracion.asp [visitado el 15/3/2015].

12 El art. 21 de la Convención Americana sobre Derechos Humanos señala:

1. Toda persona tiene derecho al uso y goce de sus bienes. La ley puede subordinar tal uso y goce al interés social.

2. Ninguna persona puede ser privada de sus bienes, excepto mediante el pago de indemnización justa, por razones de utilidad pública o de interés social y en los casos y según las formas establecidas por la ley.

3. Tanto la usura como cualquier otra forma de explotación del hombre por el hombre, deben ser prohibidas por la ley.

13 Mientras las versiones en español, portugués y francés del Pacto de San José de Costa Rica llevan el adjetivo "privada" y "privée" en el título del artículo 21, la versión en inglés solo habla de "Right to Property".

Ver Rinaldi (2009): “Le droit des populations autochtones et tribales...”, p. 216.

14 Ver en general Corte Interamericana de Derechos Humanos. 6 de febrero de 2001. Serie C No. 74 (sentencia). "Baruch Ivcher Bronstein c. Perú". 
disposición, pero ya no en su sentido tradicional de propiedad individual compuesta de tangibles e intangibles, sino de propiedad colectiva o comunal de los pueblos indígenas ${ }^{15}$.

En Awas Tingni, la Comisión Interamericana solicitó a la Corte que declare la violación del artículo 21, entre otras disposiciones convencionales, al no haber Nicaragua demarcado las tierras ancestrales de la comunidad Mayagna o Sumo que habitan la costa atlántica de dicho estado, ni haber tomado las medidas efectivas que aseguren el derecho de propiedad colectiva de esta comunidad sobre tales tierras y sus recursos naturales, "así como por haber otorgado una concesión en las tierras de la Comunidad sin su consentimiento y no haber garantizado un recurso efectivo para responder a las reclamaciones de la Comunidad sobre sus derechos de propiedad"16. La sentencia del tribunal declaró, sin ambages, que la interpretación evolutiva y más favorable a la persona del artículo 21 de la Convención Americana permite concluir que esta disposición "protege el derecho a la propiedad en un sentido que comprende, entre otros, los derechos de los miembros de las comunidades indígenas en el marco de

15 Respecto a la jurisprudencia de la Corte Interamericana sobre propiedad privada individual, posterior a Ivcher Bronstein, ver en general Corte Interamericana de Derechos Humanos. 7 de septiembre de 2004. Serie C No. 114 (sentencia). "Daniel Tibi c. Ecuador"; Corte Interamericana de Derechos Humanos. 28 de febrero de 2003. Serie C No. 98 (sentencia). "Cinco Pensionistas c. Perú"; Corte Interamericana de Derechos Humanos. 22 de noviembre de 2005. Serie C No. 135 (sentencia). "Humberto Palamara Iribarne c. Chile"; Corte Interamericana de Derechos Humanos. 1 de junio de 2006. Serie C No. 148 (sentencia). "Masacres de Ituango c. Colombia"; Corte Interamericana de Derechos Humanos. 6 de mayo de 2008. Serie C No. 179 (sentencia). "María y Julio Guillermo Salvador Chiriboga c. Ecuador"; Corte Interamericana de Derechos HumaNos. 26 de noviembre de 2008. Serie C No. 189 (sentencia). "Juan Carlos Chaparro Álvarez y Freddy Hernán Lapo Íńiguez c. Ecuador”; Corte Interamericana de Derechos HumaNos. 1 de julio de 2009. Serie C No. 198 (sentencia). "Alejandro Acevedo Buendía y Otros (Cesantes y Jubilados de la Contraloría) c. Perú"; Corte Interamericana de Derechos Humanos. 4 de marzo de 2011. Serie C No. 223 (sentencia). "Víctor Abrill Alosilla y Otros c. Perú"; Corte Interamericana de Derechos Humanos. 24 de noviembre de 2011. Serie C No. 237 (sentencia). "Familia Barrios c. Venezuela"; Corte Interamericana de Derechos Humanos. 31 de agosto de 2012. Serie C No. 246 (sentencia). "Sebastián Furlan y Familiares c. Argentina”; Corte Interamericana de Derechos Humanos. 25 de octubre de 2012. Serie C No. 252 (sentencia). "Masacres de El Mozote y Lugares Aledańos c. El Salvador"; Corte Inteamericana de Derechos Humanos. 30 de noviembre de 2012. Serie C No. 263 (sentencia). "Masacre de Santo Domingo c. Colombia"; Corte Interamericana de Derechos Humanos. 22 de agosto de 2013. Serie C No. 265 (sentencia). "Carlos y Pablo Mémoli c. Argentina"; y Corte Interamericana de Derechos Humanos. 1 de septiembre de 2015. Serie C No. 299 (sentencia). "Comunidad Campesina de Santa Bárbara c. Perú".

Ver en general López Escarcena, Sebastián (2015). "La propiedad y su privación o restricción en la jurisprudencia de la Corte Interamericana”. Ius et Praxis, Vol. $21 \mathrm{~N}^{\circ} 1$, pp. 531-76. Corte IDH. 31 de agosto de 2001 (sentencia). "Awas Tingni”, párrafo 2.

Ver también ibid., párrafos 1-4 \& 103. 
la propiedad comunal"17. Esta declaración ha sido fundamental para el posterior desarrollo de la protección convencional no solo de la propiedad indígena, sino también tribal ${ }^{18}$. A continuación, la Corte agregó un párrafo que ha sido citado reiteradamente en su jurisprudencia sobre propiedad indígena y tribal:

Entre los indígenas existe una tradición comunitaria sobre una forma comunal de la propiedad colectiva de la tierra, en el sentido de que la pertenencia de esta no se centra en un individuo sino en el grupo y su comunidad. Los indígenas por el hecho de su propia existencia tienen derecho a vivir libremente en sus propios territorios; la estrecha relación que los indígenas mantienen con la tierra debe de ser reconocida y comprendida como la base fundamental de sus culturas, su vida espiritual, su integridad y su supervivencia económica. Para las comunidades indígenas la relación con la tierra no es meramente una cuestión de posesión y producción sino un elemento material y espiritual del que deben gozar plenamente, inclusive para preservar su legado cultural y transmitirlo a las generaciones futuras ${ }^{19}$.

17 Corte IDH. 31 de agosto de 2001 (sentencia). "Awas Tingni”, párrafo 148.

Ver también ibid., párrafo 147.

El tribunal ha confirmado la aplicación de los principios de interpretación evolutiva y pro homine a la protección de la propiedad colectiva o comunal de los pueblos indígenas y tribales en Yakye Axa, Sawhoyamaxa, Saramaka, Kichwa de Sarayaku, Kuna y Emberá, Garífuna de Punta Piedra, Garifuna Triunfo de la Cruz, y Kaliña y Lokono.

Ver Corte IDH. 17 de junio de 2005 (sentencia). "Yakye Axa", párrafos 125 y 129; Corte IDH. 29 de marzo de 2006 (sentencia). "Sawhoyamaxa”, párrafo 117; Corte Interamericana de Derechos Humanos. 28 de noviembre de 2007. Serie C No. 172 (sentencia). "Pueblo Saramaka c. Surinam", párrafos 92-3 y 95; CorTe IDH. 27 de junio de 2012 (sentencia). "Kichwa de Sarayaku", párrafo 161; Corte IDH. 14 de octubre de 2014 (sentencia). "Kuna y Emberá", párrafo 113; Corte Interamericana de Derechos Humanos. 8 de octubre de 2015. Serie C No. 304 (sentencia). “Comunidad Garífuna de Punta Piedra y sus miembros c. Honduras”, párrafo 168; Corte Interamericana de Derechos Humanos. 8 de octubre de 2015. Serie C No. 305 (sentencia). "Comunidad Garífuna Triunfo de la Cruz y sus miembros c. Honduras", párrafo 103; y Corte IDH. 25 de noviembre de 2015 (sentencia). "Kalińa y Lokono", párrafo 122.

18 Ver Rinaldi (2009): "Le droit des populations autochtones et tribales...”, pp. 222-4.

19 Corte IDH. 31 de agosto de 2001 (sentencia). "Awas Tingni”, párrafo 149.

Ver Aguilar, Gonzalo (2007): Dinámica internacional de la cuestión indígena. Santiago: Librotecnia, 658 pp., en pp. 526-31.

Ver Corte Interamericana de Derechos Humanos. 15 de junio de 2005. Serie C No. 124 (sentencia). "Comunidad Moiwana c. Surinam”, párrafo 131; CorTe IDH. 17 de junio de 2005 (sentencia). "Yakye Axa”, párrafos 124, 131, 135 y 137; CoRTe IDH. 29 de marzo de 2006 (sentencia). "Sawhoyamaxa”, párrafos 118 y 121; CorTe IDH. 28 de noviembre de 2007 (sentencia). "Saramaka”, párrafos 88-91; Corte Interamericana de Derechos HuMANos. 24 de agosto de 2010. Serie C No. 214 (sentencia). "Comunidad Indígena Xákmok Kásek c. Paraguay”, párrafos 85-6 y 174-5; Corte IDH. 27 de junio de 2012 (sentencia). "Kichwa de Sarayaku", párrafos 145-6 y 212; Corte Interamericana de Derechos Humanos. 20 de noviembre de 2013. Serie C No. 270 (sentencia). "Comunidades afrodescendientes desplazadas de la cuenca del río Cacarica (Operación Génesis)”, párrafo 346; Corte Interamericana de Derechos Humanos. 29 de mayo de 2014. Serie C No. 279 
Para la determinación de estas tierras, el derecho consuetudinario de los pueblos indígenas "debe ser tenido especialmente en cuenta", de manera tal que "la posesión de la tierra debería bastar para que las comunidades indígenas que carezcan de un título real sobre la propiedad de la tierra obtengan el reconocimiento oficial de dicha propiedad y el consiguiente registro" 20 .

La legislación interna nicaragüense había reconocido la propiedad comunal de las tierras y recursos naturales que han pertenecido tradicionalmente a las comunidades indígenas de la costa atlántica, pero no había regulado el procedimiento específico para materializar dicho reconocimiento ${ }^{21}$. A la fecha de la sentencia de la Corte Interamericana, no se habían delimitado ni demarcado las tierras de la comunidad Mayagna o Sumo, ni se ha habían otorgado los títulos de propiedad colectiva correspondiente, dejando a los miembros de la comunidad indígena en un estado de incertidumbre permanente ${ }^{22}$. Como Nicaragua además había otorgado concesiones a terceros para la explotación de los bienes ubicados en un área que podría corresponder, en todo o parte, a los terrenos sobre los que el estado demandado debería haber demarcado, delimitado y otorgado títulos de propiedad a favor de la comunidad Mayagna o Sumo, el tribunal estimó que Nicaragua violó el artículo 21 de la Convención Americana, en perjuicio de los miembros de dicha comunidad ${ }^{23}$.

En su voto concurrente en Awas Tingni, el juez Sergio García Ramírez reiteró la pertinencia de la aplicación de los principios evolutivo y no restrictivo, así como de otros instrumentos jurídicos internacionales, en

(sentencia). "Segundo Norín Catrimán y otros (Dirigentes, miembros y activistas del pueblo indígena Mapuche) c. Chile”, párrafo 155; CoRTe IDH. 14 de octubre de 2014 (sentencia). "Kuna y Emberá", párrafo 111; CoRTe IDH. 8 de octubre de 2015 (sentencia). "Garífuna de Punta Piedra”, párrafo 165; Corte IDH. 8 de octubre de 2015 (sentencia). "Garífuna Triunfo de la Cruz", párrafo 100; y CorTe IDH. 25 de noviembre de 2015 (sentencia). "Kaliña y Lokono", párrafo 129.

Ver también Rodríguez-Piñero (2006): "El sistema interamericano de derechos humanos...”, pp. 187-8; y RodrígueZ-Piñero (2013): “La sentencia...”, pp. 131-2.

20 Corte IDH. 31 de agosto de 2001 (sentencia). "Awas Tingni”, párrafo 151.

Ver Rodríguez-Piñero (2006): “El sistema interamericano de derechos humanos...”, pp. 189-90; NASH, Claudio (2008). "Los derechos indígenas en el sistema interamericano de derechos humanos". 1/I Inter-American and European Human Rights Journal, Vol. $1 \mathrm{~N}^{\circ} 1$, pp. 61-86, en p. 70; y Rinaldi (2009): "Le droit des populations autochtones et tribales...”, pp. 224-5.

Ver también Anaya y Williams (2001). “The Protection of Indigenous Peoples' Rights...”, pp. 43-4.

21 Ver CoRte IDH. 31 de agosto de 2001 (sentencia). “Awas Tingni”, párrafos 150 y 152.

22 Ver Corte IDH. 31 de agosto de 2001 (sentencia). "Awas Tingni”, párrafo 153.

23 Ver Conte IDH. 31 de agosto de 2001 (sentencia). "Awas Tingni”, párrafos 153 y 155. 
la interpretación del artículo 21 del Pacto de San José de Costa Rica ${ }^{24}$. Este juez asimismo consideró que la decisión de la Corte de reconocer los derechos de propiedad de los miembros de la comunidad Mayagna o Sumo "no implica en modo alguno desconocer o negar derechos de otra naturaleza o alcance vinculados con aquellos, como son los de carácter colectivo" ${ }^{25}$. Al respecto, agregó el juez García Ramírez que:

Es indispensable observar que estos derechos comunitarios, que forman parte entrańable de la cultura jurídica de muchos pueblos indígenas, y por lo tanto de sus integrantes, constituyen la fuente y el amparo de los derechos subjetivos individuales. En suma, existe una íntima e indisoluble vinculación entre los derechos de ambos órdenes -individuales y colectivos-, de cuya vigencia efectiva depende la genuina tutela de las personas que forman parte de los grupos étnicos indígenas ${ }^{26}$.

24 Anticipándose a Yakye Axa, el juez García Ramírez hizo referencia al Convenio $\mathrm{N}^{\circ} 169$ de la Organización Internacional del Trabajo de 1989.

Ver Corte Interamericana de Derechos Humanos. 31 de agosto de 2001. Serie C No. 79 (voto concurrente del juez García Ramírez). "Comunidad Mayagna (Sumo) Awas Tingni c. Nicaragua", párrafos 2-8.

Ver también Corte IDH. 17 de junio de 2005 (sentencia). "Yakye Axa”, párrafos 126-31, $135-7 \& 143-51$.

El Convenio No 169 de la OIT, sobre Pueblos Indígenas y Tribales en Países Independientes, entró en vigencia en 1991 y está disponible en

http://www.ilo.org/dyn/normlex/es/f?p=NORMLEXPUB:12100:0::NO:12100:P12100_ INSTRUMENT_ID:312314:NO [visitado el 15/3/2015].

El juez García Ramírez también se refirió en su voto concurrente en Awas Tingni al proyecto de Declaración Americana sobre los Derechos de los Pueblos Indígenas de la Organización de Estados Americanos.

Ver CoRte IDH. 31 de agosto de 2001 (voto concurrente del juez García Ramírez). “Awas Tingni”, párrafo 9.

Este instrumento jurídico fue solicitado por la Asamblea General de la Organización de los Estados Americanos en 1989 a la Comisión Interamericana de Derechos Humanos, la cual preparó un proyecto de declaración que aprobó en 1997 y dejó a disposición de la Asamblea General ese año. En 1999, la Asamblea General estableció un grupo de trabajo del Consejo Permanente de la OEA.

El proyecto de Declaración Americana sobre los Derechos de los Pueblos Indígenas de la OEA está disponible en: http://www.cidh.org/Indigenas/Cap.2g.htm [visitado el $15 / 3 / 2015]$.

Sobre el proyecto de Declaración Americana sobre los Derechos de los Pueblos Indígenas ver MacKay, Fergus (2002): Guide to Indigenous Peoples' Rights in the Inter-American Human Rights System. Copenhagen: International Work Group for Indigenous Affairs, 171 pp., en pp. 97-138; Hannum (2003): “Indigenous Rights.", pp. 90-3; Dannenmaier (2008).

"Beyond Indigenous Property...", pp. 74-6; PAsQualucci (2009). "International Indigenous...”, p. 54; y UN Permanent Forum on Indigenous Peoples (2009): State of the World's..., p. 199.

25 Corte IDH. 31 de agosto de 2001 (voto concurrente del juez García Ramírez). "Awas Tingni”, párrafo 14 .

26 Corte IDH. 31 de agosto de 2001 (voto concurrente del juez García Ramírez). "Awas Tingni”, párrafo 14 .

Ver ibid., párrafo 15. 


\section{2) PUEBLOS INDÍGENAS Y TAMBIÉN TRIBALES}

La doctrina internacional no tardó en dirigir su atención a la sentencia de la Corte en Awas Tingni ${ }^{27}$. Tres años más tarde, el tribunal condenó a Guatemala por violar el artículo 21 de la Convención Americana en contra de los miembros del pueblo indígena maya Achí que habitaban la aldea llamada Plan de Sánchez, como consecuencia de la así denominada masacre que el ejército de ese estado y colaboradores civiles ejecutaron en contra de ellos, previo reconocimiento guatemalteco de los hechos constitutivos de este caso $^{28}$. El artículo 21 recibió un mayor desarrollo jurisprudencial casi un año después en otra sentencia condenatoria, esta vez en contra de Surinam. Moiwana es el nombre de la comunidad maroon N'djuka, compuesta por afrodescendientes de esclavos fugitivos que fundaron una aldea en la parte oriental de Surinam. Durante el conflicto interno que afectó a este país en la década de 1980, se efectuó una operación militar en dicha aldea contra las fuerzas armadas opositoras al gobierno de facto, en la cual se mató e hirió a miembros de la comunidad N'djuka, destruyendo su propiedad y forzando a los sobrevivientes a huir. La aldea de Moiwana quedó abandonada desde que sus habitantes fueran desplazados por el ejército de Surinam ${ }^{29}$.

En Comunidad Moiwana (2005), la Corte Interamericana tuvo que determinar si la aldea pertenecía a los miembros de la comunidad N'djuka, para así establecer si hubo una privación de su propiedad colectiva derivada de la operación militar que Surinam no investigó ni sancionó ${ }^{30}$. Como en Awas Tingni, los miembros de la comunidad no tenían un título legal formal, sea individual o colectivo, sobre sus tierras tradicionales y los territorios circundantes ${ }^{31}$. Citando esta sentencia, el tribunal señaló que:

27 Ver e.g. Anaya y Grossman (2002). “The Case of Awas Tingni...”, pp. 1-15; Vuotto, Jonathan (2004). "Awas Tingni v. Nicaragua: International Precedent for Indigenous Land Rights”. Boston University International Law Journal, Vol. 22 No 22, pp. 219-43; y ALVARADO, Leonardo (2007). "Prospects and Challenges in the Implementation of Indigenous Peoples' Human Rights in International Law: Lessons from the Case of Awas Tingni v. Nicaragua". Arizona Journal of International and Comparative Law, Vol. 24, pp. 609-43.

Ver en general Gómez Isa, Felipe (ed.) (2013): El caso Awas Tingni. Derechos humanos entre lo local y lo global. Bilbao: Publicaciones de la Universidad de Deusto, 251 pp.

28 Ver en general Corte Interamericana de Derechos Humanos. 19 de noviembre 2004. Serie C No. 116 (sentencia). "Masacre Plan de Sánchez c. Guatemala”.

Ver también Weckel y Rinaldi (2008): "Relativisme culturel ou universalité... pp. 424-5.

29 Ver Corte IDH. 15 de junio de 2005 (sentencia). "Moiwana”, párrafos 1-3 y 86.

30 Ver Corte IDH. 15 de junio de 2005 (sentencia). "Moiwana”, párrafos 128-9.

31 Ver Corte IDH. 15 de junio de 2005 (sentencia). "Moiwana”, párrafo 130. 
[para las] comunidades indígenas que han ocupado sus tierras ancestrales de acuerdo con sus prácticas consuetudinarias - pero que carecen de un título formal de propiedad- la posesión de la tierra debería bastar para que obtengan el reconocimiento oficial de dicha propiedad y el consiguiente registro ${ }^{32}$.

Puesto que los miembros de la comunidad N'djuka no son indígenas a la región de la cual fueron desplazados de manera forzada, la Corte se preguntó si estas consideraciones provenientes de Awas Tingni debieran hacerse extensivas a un "pueblo tribal" compuesto por maroons que "poseen una 'relación omnicomprensiva' con sus tierras tradicionales, y su concepto de propiedad en relación con ese territorio no se centra en el individuo, sino en la comunidad como un todo"33. Sin mayor dificultad, la Corte concluyó que la jurisprudencia sobre propiedad colectiva indígena es aplicable a la comunidad N'djuka, por lo que su "ocupación tradicional de la aldea Moiwana y las tierras circundantes" es suficiente para obtener el reconocimiento de ese territorio, cuyos límites exactos deben determinarse previa consulta con las comunidades indígenas vecinas ${ }^{34}$.

32 Corte IDH. 15 de junio de 2005 (sentencia). "Moiwana”, párrafo 131.

Ver CoRTe IDH. 31 de agosto de 2001 (sentencia). "Awas Tingni”, párrafos 149 y 151.

33 Corte IDH. 15 de junio de 2005 (sentencia). "Moiwana”, párrafo 133.

Ver ibid., párrafo 132.

34 Ver CoRTe IDH. 15 de junio de 2005 (sentencia). “Moiwana”, párrafo 133.

Sobre el derecho de consulta indígena y tribal en el derecho internacional ver OrganizAción Internacional del Trabajo (2009): Los derechos de los pueblos indigenas y tribales en la práctica - Una guía sobre el Convenio $N^{\circ} 169$ de la OIT. Ginebra: Publicaciones de la OIT, 200 pp., en pp. 59-66 \& 107-15; Pasqualucci, Jo (2009). "International Indigenous Land Rights: A Critique of the Jurisprudence of the Inter-American Court of Human Rights in Light of the United Nations Declaration on the Rights of Indigenous Peoples". Wisconsin International Law Journal, Vol. $27 \mathrm{~N}^{\circ} 1$, pp. 51-98, en pp. 86-91; Forero (2010). "Conectividad: alcances del derecho a la propiedad...", pp. 199-203; Rodríguez Garavito y Morris (eds.) (2010): La consulta previa..., pp. 31-5 \& 41-83; Yupsanis, Athanasios (2010). "ILO Convention No. 169 Concerning Indigenous and Tribal Peoples in Independent Countries 1989-2009: An Overview". Nordic Journal of International Law, Vol. $79 \mathrm{~N}^{\circ}$ 3, pp. 433-56, en pp. 438-50; Pentassuglia (2011). "Towards a Jurisprudential...", pp. 176-82; SAlmón, Elizabeth (2011): Jurisprudencia de la Corte Interamericana de Derechos Humanos. Bogotá: Editorial Universidad del Rosario, 257 pp., en pp. 219-23; Schettini (2012). "Por un nuevo paradigma de protección...", pp. 77-81; y Ruiz ChiriBoga y Donoso (2014): "Pueblos indígenas y la Corte Interamericana...”, pp. 984-93.

Ver también Anaya y Williams (2001). "The Protection of Indigenous Peoples' Rights...”, pp. 77-84; Anaya, James (2005). "Indigenous Peoples' Participatory Rights in Relation to Decisions about Natural Resource Extraction: The More Fundamental Issue of What Rights Indigenous Peoples Have in Lands and Resources". Arizona Journal of International and Comparative Law, Vol. 22, pp. 7-17; Gómez, Magdalena (2006): "El Convenio 169 de la Organización Internacional del Trabajo”. En Berraondo, Mikel (ed.): Pueblos indígenas y derechos humanos. Bilbao: Publicaciones de la Universidad de Deusto, pp. 133-51, en pp. 142-4 \& 146-9; Olivares, Efrén (2013). “Indigenous Peoples' Rights and the Extractive Industry: Jurisprudence from the Inter-American System of Human Rights”. Goettingen 
El tribunal resolvió que la negación de este derecho de propiedad comunal por Surinam, provocada por la operación militar y la posterior falta de investigación y sanción de sus hechos, constituyó una violación del artículo 21 de la Convención Americana en perjuicio de los miembros de la comunidad maroon ${ }^{35}$.

Un par de días después de dictar la sentencia en Moiwana, la Corte resolvió Comunidad indígena Yakye Axa (2005): el primero de tres casos presentados en contra de Paraguay por violar el derecho de propiedad colectiva o comunal de pueblos indígenas de la región del Chaco, en perjuicio de sus integrantes ${ }^{36}$. Todas estas sentencias condenatorias recibieron atención doctrinal, aunque menor a la dedicada a Awas Tingni ${ }^{37}$. Tanto en Yakye Axa, como en Comunidad indigena Sawhoyamaxa (2006) y en Comunidad indígena Xákmok Kásek (2010), la Comisión Interamericana demandó a Paraguay por no haber resuelto satisfactoriamente las solicitudes de reivindicación territorial presentadas por pueblos multiétnicos de mayoría Enxet a comienzos de la década de 1990, dejando a los miembros de dichas comunidades indígenas en un estado de vulnerabilidad tal, que su propia sobrevivencia quedó amenazada ${ }^{38}$.

Utilizando las reglas de interpretación del artículo 31 de la Convención de Viena sobre el Derecho de los Tratados, la sentencia de la Corte en Yakye Axa analizó por primera vez el artículo 21 del Pacto de San José de Costa Rica a la luz de las disposiciones del Convenio No 169 de la

Journal of International Law, Vol. 5 № 1, pp. 187-214; y PATiŃo, Luz (2014). "Fundamentos y práctica internacional del derecho a la consulta previa, libre e informada a pueblos indígenas". Anuario Colombiano de Derecho Internacional, Vol. 7, pp. 69-111.

Ver CoRTe IDH. 15 de junio de 2005 (sentencia). "Moiwana", párrafos 134-5 \& 233.

36 Ver Corte IDH. 17 de junio de 2005 (sentencia). "Yakye Axa", párrafos 156 \& 242; Corte IDH. 29 de marzo de 2006 (sentencia). "Sawhoyamaxa", párrafos 144 \& 248; y CorTe IDH. 24 de agosto de 2010 (sentencia). "Xákmok Kásek”, párrafos 170, 182 \& 337.

37 Ver e.g. Fuentes, Carlos Iván (2005). "Universalidad y diversidad cultural en la interpretación de la Convención Americana sobre Derechos Humanos: Innovaciones en el caso de la Comunidad Indígena Yakye Axa". Revista CEJIL, Vol. 1 No 2, pp. 69-77; y Ramírez, Andrés (2005). "El caso de la comunidad indígena Yakye Axa vs. Paraguay". Revista IIDH, Vol. 41, pp. 347-64; Martin, Claudia (2006). "The Moiwana Village Case: A New Trend in Approaching the Rights of Ethnic Groups in the Inter-American System". Leiden Journal of International Law, Vol. 19, No 2, pp. 491-504; OrmacheA, Pablo (2006). "Moiwana Village: The Inter-American Court and the Continuing Violation Doctrine Recent Developments". Harvard Human Rights Journal, Vol. 19, pp. 283-8; y Anткоwiak, Thomas (2007). "Moiwana Village v. Suriname: A Portal into Recent Jurisprudential Developments of the Inter-American Court of Human Rights". Berkeley Journal of International Law, Vol. 25, pp. $268-82$.

38 Ver Corte IDH. 17 de junio de 2005 (sentencia). "Yakye Axa", párrafos 1-3; Corte IDH. 29 de marzo de 2006 (sentencia). "Sawhoyamaxa", párrafos 1-3; y CorTe IDH. 24 de agosto de 2010 (sentencia). "Xákmok Kásek”, párrafos 1-5. 
Organización Internacional del Trabajo de $1989^{39}$. Desde este punto de vista, el tribunal consideró que el especial significado que tienen para la identidad cultural de los pueblos indígenas sus tierras y territorios ancestrales o tradicionales, y sus recursos naturales, encuentra su expresión convencional en el artículo 13 del Convenio No 169 de la OIT ${ }^{40}$. Para la Corte, la protección ofrecida por el artículo 21 de la Convención Americana al derecho de propiedad colectiva o comunal de los pueblos indígenas o tribales carecería de sentido, si el reconocimiento jurídico abstracto de estas tierras, territorios y recursos naturales no va acompañado de la delimitación de la propiedad respectiva, y de su demarcación física ${ }^{41}$.

39 Ver CoRte IDH. 17 de junio de 2005 (sentencia). "Yakye Axa”, párrafos 126-31, 135-7 \&143-51.

Ver también Rinaldi (2009): “Le droit des populations autochtones et tribales...”, pp. 226-7. Respecto al Convenio No 169 de la OIT ver Swepston, Lee (1990). "A New Step in the International Law on Indigenous and Tribal Peoples: the ILO Convention No. 169 of 1989”. Oklahoma City University Law Review, Vol. $15 \mathrm{~N}^{\circ}$ 3, pp. 677-714; Thornberry (2002): Indigenous peoples..., pp. 339-67; Hannum (2003): "Indigenous Rights.", pp. 87-8; AnAYA, James (2004): Indigenous Peoples in International Law. Nueva York: Oxford University Press, 396 pp., en pp. 53-61 \& 226-8; Gómez (2006): "El Convenio 169 de la Organización Internacional del Trabajo”, pp. 133-51; Aguilar (2007): Dinámica internacional..., pp. 62-9; Bengoa, José (2007): La emergencia indigena en América Latina. Santiago: Fondo de Cultura Económica, 343 pp., en pp. 270-5; Dannenmaier, Eric (2008). "Beyond Indigenous Property Rights: Exploring the Emergence of a Distinctive Connection Doctrine". Washington University Law Review, Vol. 86, pp. 53-110, en pp. 69-70; UN Permanent Forum on Indigenous Peoples (2009): State of the World's Indigenous Peoples. Nueva York: Publicaciones de la ONU, 238 pp., en pp. 200-1; Xanthaki, Alexandra (2010): Indigenous Rights and United Nations Standards: Self-determination, Culture and Land. Nueva York: Cambridge University Press, 314 pp., en pp. 67-91; Yupsanis (2010). "ILO Convention No. 169...", pp. 433-56; Marcelli, Fabio (2011): Los derechos de los pueblos indígenas. Medellín: Librería Jurídica Sánchez, 177 pp., en pp. 69-77; Hervé, Dominique, y PÉrez, Sergio (2012): "Adecuación de la legislación interna a los estándares impuestos para la administración de recursos naturales". En Contesse, Jorge (ed.): El Convenio 169 de la OIT y el derecho chileno. Mecanismos y obstáculos para su implementación. Santiago: Ediciones Universidad Diego Portales, pp. 15-101, en pp. 23-31; Olivares (2013). "Indigenous Peoples' Rights...", pp. 189-91; y Meza-Lopehandía, Matías (2014): "El Convenio No 169 sobre pueblos indígenas y tribales de la Organización Internacional del Trabajo”. En Aylwin, José (ed.): Los pueblos indigenas y el derecho. Santiago: Lom Ediciones, pp. 337-439.

Ver en general Rodríguez-Piñero, Luis (2005): Indigenous Peoples, Postcolonialism and International Law: the ILO Regime (1919-1989). Oxford: Oxford University Press, 410 pp.

La Convención de Viena sobre el Derecho de los Tratados, en vigor desde 1980, está disponible en: http://www.wipo.int/export/sites/www/wipolex/es/glossary/vienna-convention-es. pdf [visitado el 15/3/2015].

Sobre la interpretación de tratados ver en general LinderfalK, Ulf (2007): On the Interpretation of Treaties: The Modern International Law as Expressed in the 1969 Vienna Convention on the Law of Treaties. Dordrecht: Springer, 440 pp.; y Gardiner, Richard (2010): Treaty Interpretation. Oxford: Oxford University Press, 409 pp.

40 Ver CoRTe IDH. 17 de junio de 2005 (sentencia). "Yakye Axa”, párrafos 135-67.

Ver también Corte IDH. 31 de agosto de 2001 (sentencia). "Awas Tingni”, párrafo 149.

Ver Corte IDH. 17 de junio de 2005 (sentencia). "Yakye Axa”, párrafo 143. 
Debido a que se pueden presentar contradicciones reales o aparentes entre propiedades colectivas de pueblos indígenas o tribales y propiedades individuales de simples particulares, la sentencia ofreció cuatro pautas para determinar cuándo una restricción al derecho de propiedad privada colectiva o individual es admisible. Según la Corte, la limitación respectiva debe ser: establecida por ley, necesaria, proporcional y orientada a "un objeto legítimo en una sociedad democrática" ${ }^{42}$. Como explicó a continuación el tribunal:

[...] La necesidad de las restricciones legalmente contempladas dependerá de que estén orientadas a satisfacer un interés público imperativo, siendo insuficiente que se demuestre, por ejemplo, que la ley cumple un propósito útil u oportuno. La proporcionalidad radica en que la restricción debe ajustarse estrechamente al logro de un legítimo objetivo, interfiriendo en la menor medida posible en el efectivo ejercicio del derecho restringido. Finalmente, para que sean compatibles con la Convención las restricciones deben justificarse según objetivos colectivos que, por su importancia, preponderen claramente sobre la necesidad del pleno goce del derecho restringido ${ }^{43}$.

En aplicación de estos criterios, la Corte concluyó que en caso de conflicto entre la propiedad comunal indígena o tribal y la propiedad individual particular, por regla general debiera prevalecer la primera sobre la segunda. Esto, por cuando la restricción de la propiedad comunal indígena y tribal afectaría otros derechos del pueblo indígena o tribal correspondiente $-i$.e., los derechos a su identidad cultural y a su sobrevivencia- ${ }^{44}$. Por el contrario, agregó el tribunal:

[...] la restricción que se haga al derecho a la propiedad privada de particulares pudiera ser necesaria para lograr el objetivo colectivo de preservar las identidades culturales en una sociedad democrática y pluralista en el sentido de la Convención Americana; y proporcional,

42 Corte IDH. 17 de junio de 2005 (sentencia). "Yakye Axa”, párrafo 144.

43 Corte IDH. 17 de junio de 2005 (sentencia). "Yakye Axa”, párrafo 145.

44 Ver Corte IDH. 17 de junio de 2005 (sentencia). "Yakye Axa”, párrafos 146-7.

Ver también Weckel y Rinaldi (2008): "Relativisme culturel ou universalité... pp. 429-30. Sobre el derecho a la identidad cultural ver Rinaldi (2009): "Le droit des populations autochtones et tribales...", pp. 241-4; Forero (2010). "Conectividad: alcances del derecho a la propiedad...”, pp. 192-4; y Rodríguez-Piñero (2013): “El impacto internacional...”, en pp. 170-3.

Ver en general Ruiz Chiriboga, Oswaldo (2006). "El derecho a la identidad cultural de los pueblos indígenas y las minorías nacionales: una mirada desde el sistema interamericano". Sur - Revista Internacional de Derechos Humanos, Vol. 5, pp. 42-69. 
si se hace el pago de una justa indemnización a los perjudicados, de conformidad con el artículo 21.2 de la Convención ${ }^{45}$.

Al ser una regla general, la sentencia señaló que no siempre que estén en conflicto ambos tipos de propiedad primará el derecho de los pueblos indígenas o tribales sobre el de los simples particulares. Así:

Cuando los Estados se vean imposibilitados, por razones concretas y justificadas, de adoptar medidas para devolver el territorio tradicional y los recursos comunales de las poblaciones indígenas, la compensación que se otorgue debe tener como orientación principal el significado que tiene la tierra para estas ${ }^{46}$.

Relacionando el artículo 21 de la Convención Americana con el Convenio No 169 de la OIT, la sentencia declaró que "[l]a elección y entrega de tierras alternativas, el pago de una justa indemnización o ambos no quedan sujetas a criterios meramente discrecionales del Estado", sino que deben ser "consensuadas con los pueblos interesados, conforme a sus propios procedimientos de consulta, valores, usos y derecho consuetudinario $^{47}$.

En su voto parcialmente disidente en Yakye Axa, el juez Alirio Abreu destacó la importancia de recurrir a otros instrumentos jurídicos internacionales y de concordar el artículo 21 con otras disposiciones del Pacto de San José de Costa Rica, a fin de proteger la identidad cultural de los pueblos indígenas y tribales, que no está expresamente consagrada en el texto convencional ${ }^{48}$.

\section{3) SENTENCIAS QUE CONFIRMAN UNA TENDENCIA}

Sawhoyamaxa es el segundo caso fallado en contra de Paraguay, relacionado con las reclamaciones territoriales de pueblos mayoritariamente

\footnotetext{
45 Corte IDH. 17 de junio de 2005 (sentencia). "Yakye Axa”, párrafo 148.

46 Corte IDH. 17 de junio de 2005 (sentencia). "Yakye Axa”, párrafo 149.

Ver Rinaldi (2009): "Le droit des populations autochtones et tribales...", pp. 236-8.

47 Corte IDH. 17 de junio de 2005 (sentencia). "Yakye Axa”, párrafo 151.

Ver CoRte IDH. 17 de junio de 2005 (sentencia). "Yakye Axa”, párrafo 150.

48 Ver Corte Interamericana de Derechos Humanos. 17 de junio de 2005. Serie C No. 125 (voto parcialmente disidente del juez Abreu). "Comunidad Indígena Yakye Axa c. Paraguay", párrafos 19-36.

El juez Abreu mencionó el art. XIII de la Declaración Americana de los Derechos y Deberes del Hombre, y el art. 14 del denominado Protocolo de San Salvador, sobre derechos económicos, sociales y culturales, así como los arts. 1.1, 5, 11-3, 15-8, 21 y 23-4 del Pacto de San José de Costa Rica.
} 
Enxet del Chaco. En su sentencia, la Corte Interamericana insistió en los criterios expuestos en Awas Tingni y Yakye Axa, agregó otros e intentó por primera vez sistematizar su aproximación jurisprudencial a la propiedad comunal indígena y tribal. Desde el inicio de sus consideraciones sobre el artículo 21 de la Convención Americana, el tribunal volvió a vincular la interpretación de esta disposición con el Convenio No 169 de la OIT ${ }^{49}$. Este punto de vista le permitió responder tres preguntas: ¿es la posesión de las tierras un requisito para obtener el reconocimiento oficial de propiedad colectiva indígena o tribal?; en caso de no serlo, ¿tiene el derecho de devolución de dichas tierras un límite temporal?; y en este escenario ¿qué acciones debe adoptar el estado para hacer efectivo el derecho de propiedad comunal indígena o tribal? ${ }^{50}$ En cuanto a la primera de estas preguntas, la sentencia declaró:

1) la posesión tradicional de los indígenas sobre sus tierras tiene efectos equivalentes al título de pleno dominio que otorga el Estado; 2) la posesión tradicional otorga a los indígenas el derecho a exigir el reconocimiento oficial de propiedad y su registro; 3) los miembros de los pueblos indígenas que por causas ajenas a su voluntad han salido o perdido la posesión de sus tierras tradicionales mantienen el derecho de propiedad sobre las mismas, aún a falta de título legal, salvo cuando las tierras hayan sido legítimamente trasladas a terceros de buena fe; y 4) los miembros de los pueblos indígenas que involuntariamente han perdido la posesión de sus tierras, y estas han sido trasladas legítimamente a terceros inocentes, tienen el derecho de recuperarlas o a obtener otras tierras de igual extensión y calidad ${ }^{51}$.

Para contestar a la segunda pregunta, la Corte recordó que la identidad de los pueblos indígenas y tribales depende en gran medida de la relación que tengan con sus tierras tradicionales, por lo que "[m]ientras esa relación exista, el derecho a la reivindicación permanecerá vigente, caso contrario, se extinguirá" 52 . De acuerdo a la sentencia:

Dicha relación puede expresarse de distintas maneras, según el pueblo indígena del que se trate y las circunstancias concretas en que

49 Ver CoRte IDH. 29 de marzo de 2006 (sentencia). “Sawhoyamaxa”, párrafos 117 y 119.

Ver también Conte IDH. 17 de junio de 2005 (sentencia). "Yakye Axa”, párrafos 127-30, 136 y $150-1$.

50 Ver Corte IDH. 29 de marzo de 2006 (sentencia). “Sawhoyamaxa”, párrafo 126.

51 Corte IDH. 29 de marzo de 2006 (sentencia). "Sawhoyamaxa”, párrafo 128.

Ver Corte IDH. 31 de agosto de 2001 (sentencia). "Awas Tingni”, párrafo 151; Corte IDH. 15 de junio de 2005 (sentencia). "Moiwana”, párrafo 134; y CorTe IDH. 17 de junio de 2005 (sentencia). "Yakye Axa”, párrafos 141, 152, 155-6, 233, 235 y 242.

Ver también Weckel y Rinaldi (2008): "Relativisme culturel ou universalité... pp. 430-1.

52 Corte IDH. 29 de marzo de 2006 (sentencia). "Sawhoyamaxa”, párrafo 131. 
se encuentre, y puede incluir el uso o presencia tradicional, ya sea a través de lazos espirituales o ceremoniales; asentamientos o cultivos esporádicos; caza, pesca o recolección estacional o nómada; uso de recursos naturales ligados a sus costumbres; y cualquier otro elemento característico de su cultura ${ }^{53}$.

Esta relación del pueblo indígena o tribal con sus tierras requiere, además, ser posible. En otras palabras, la comunidad respectiva no debe verse impedida de realizar sus actividades tradicionales por causas ajenas a su voluntad, que impliquen un obstáculo real a dicha relación. De existir tales impedimentos, su derecho a la recuperación de su propiedad colectiva persistirá hasta que estos desaparezcan ${ }^{54}$.

Respecto a la tercera pregunta que se hiciera el tribunal, la sentencia declaró que una vez probado que el derecho de recuperación de las tierras tradicionales perdidas está vigente, corresponde al Estado devolverlas ${ }^{55}$. Excepcionalmente, no tendrá que hacerlo cuando se vea imposibilitado "por motivos objetivos y fundamentados" de adoptar las medidas que permitan su devolución, debiendo en este caso entregar tierras alternativas "de igual extensión y calidad" o pagar una indemnización justa, siempre que haya consultado antes a los miembros del pueblo en cuestión ${ }^{56}$. Para el tribunal, el hecho que las tierras reclamadas estén en manos privadas "no constituye per se un motivo 'objetivo y fundamentado' suficiente para denegar prima facie las solicitudes indígenas”, ya que:

En caso contrario, el derecho a la devolución carecería de sentido y no ofrecería una posibilidad real de recuperar las tierras tradicionales, limitándose únicamente a esperar la voluntad de los tenedores actuales, y forzando a los indígenas a aceptar tierras alternativas o indemnizaciones pecuniarias 57 .

Tampoco sería necesariamente objetiva y fundamentada la negativa dada a una reclamación de tierras tradicionales basada en el hecho que están siendo explotadas de manera productiva por terceros. En la opinión

53 Corte IDH. 29 de marzo de 2006 (sentencia). "Sawhoyamaxa”, párrafo 131.

Ver Conte IDH. 17 de junio de 2005 (sentencia). "Yakye Axa”, párrafo 154.

Ver también Rodríguez-PiÑero (2006): "El sistema interamericano de derechos humanos...”, pp. 195-6; SAlmón (2011): Jurisprudencia de la Corte..., pp. 213-4; RodríguezPiñero (2013): “El impacto internacional...”, pp. 181-3; y Ruiz Chiriboga y Donoso (2014): "Pueblos indígenas y la Corte Interamericana...", p. 977.

54 Ver Corte IDH. 29 de marzo de 2006 (sentencia). "Sawhoyamaxa”, párrafo 132.

55 Ver Corte IDH. 29 de marzo de 2006 (sentencia). "Sawhoyamaxa”, párrafo 135.

56 Corte IDH. 29 de marzo de 2006 (sentencia). "Sawhoyamaxa”, párrafo 135.

Ver Corte IDH. 17 de junio de 2005 (sentencia). "Yakye Axa”, párrafo 149.

57 Corte IDH. 29 de marzo de 2006 (sentencia). "Sawhoyamaxa”, párrafo 138. 
de la Corte, esto supondría reducir la "cuestión indígena" a un problema agrario o industrial, siendo que excede con mucho ese solo aspecto ${ }^{58}$. De haber un conflicto entre el derecho de propiedad colectiva indígena o tribal y el de propiedad individual particular, indicó el tribunal, debe estudiarse caso a caso la legalidad, necesidad, proporcionalidad y utilidad pública o interés social de la limitación o restricción de los derechos involucrados, tanto de los pueblos indígenas o tribales como de los particulares $^{59}$.

Debido a que el tribunal consideró como parte lesionada y beneficiaria de las reparaciones dictadas a los miembros de la comunidad indígena, como lo había hecho anteriormente en Awas Tingni y Yakye Axa, el juez Sergio García Ramírez agregó un voto razonado a Sawhoyamaxa, donde declaró:

En el asunto que se ha resuelto a través de la sentencia a la que agrego este Voto, los miembros de una comunidad indígena se vieron privados de bienes que les habían pertenecido bajo títulos ancestrales. Una vez más, la Corte ha debido observar los derechos comunitarios desde el lente, que autoriza el artículo 1.2 de la Convención Americana, de los derechos correspondientes a seres humanos. De ahí que se refiera a los integrantes o miembros de los grupos indígenas, y no necesariamente a estos mismos. La perspectiva convencional, que constituye el marco para la competencia de la Corte, no sig-

58 Ver Corte IDH. 29 de marzo de 2006 (sentencia). “Sawhoyamaxa”, párrafos 138-9.

La Corte analizó una tercera posibilidad de negativa estatal a la solicitud de devolución de tierras tradicionales: que estas pertenezcan a un extranjero que se encuentre protegido por un tratado bilateral de inversión. Según el tribunal, esto no constituiría un inconveniente por dos razones. Primero, porque este tipo de tratados consagran el derecho del Estado anfitrión para expropiar o nacionalizar la propiedad de los extranjeros cubiertos por dicho acuerdo internacional, cumpliendo ciertos requisitos. Y, segundo, porque la aplicación de un tratado bilateral de inversión no justifica el incumplimiento de las disposiciones de la Convención Americana, cuya "especificidad propia" de tratado multilateral de derechos humanos hace que no dependa enteramente de la reciprocidad de los estados.

Ver Corte IDH. 29 de marzo de 2006 (sentencia). "Sawhoyamaxa”, párrafo 140.

Cf. Nikken, Pedro (2009): "Balancing of Human Rights and Investment Law in the InterAmerican System of Human Rights". En Dupuy, Pierre-Marie, Francioni, Francesco, y Petersmann, Ernst-Ulrich (eds.): Human Rights in International Investment Law and Arbitration. Oxford: Oxford University Press, pp. 246-71, en pp. 265-70.

Sobre los tratados de inversión ver Newcombe, Andrew, y Paradell, Lluís (2009): Law and Practice of Investment Treaties: Standards of Treatment. Alphen aan den Rijn: Kluwer Law International, 614 pp.; Salacuse, Jeswald (2010): The Law of International Investment Treaties. Oxford: Oxford University Press, 517 pp.; y Dolzer, Rudolf, y Schreuer, Christoph (2012): Principles of International Investment Law. Oxford: Oxford University Press, 456 pp. En cuanto a la expropriación en el derecho internacional ver López EsCarcena (2014): Indirect Expropriation...

59 Ver Corte IDH. 29 de marzo de 2006 (sentencia). "Sawhoyamaxa”, párrafo 138.

Ver también Corte IDH. 17 de junio de 2005 (sentencia). "Yakye Axa”, párrafos 144-6. 
nifica en modo alguno desconocimiento o reserva frente a derechos colectivos $^{60}$.

En Xákmok Kásek, su tercera sentencia contra Paraguay por violación del artículo 21, la Corte Interamericana explicitó un deber estatal subyacente en su jurisprudencia sobre propiedad colectiva indígena y tribal desde Awas Tingni -la obligación estatal de delimitar, demarcar y otorgar un título colectivo a las tierras de la comunidad indígena o tribal correspondiente- ${ }^{61}$. De esta forma, los cuatro criterios desarrollados en Sawhoyamaxa pasaron a ser cinco ${ }^{62}$. Como señaló la Corte en Xákmok Kásek: a) la posesión tradicional de las tierras equivale a un título pleno de dominio; b) esta posesión otorga el derecho a exigir el reconocimiento y registro estatal de las tierras respectivas; c) el Estado tiene la obligación de delimitarlas, demarcarlas y otorgar un título de dominio colectivo; d) de haberse perdido la posesión de tales tierras por causas ajenas a la voluntad de la comunidad indígena o tribal, esta mantiene su derecho de propiedad, incluso cuando hayan sido legítimamente transferidas a terceros de buena fe; e) en cuyo caso la comunidad tiene el derecho de recuperarlas o de obtener otras de igual extensión y calidad ${ }^{63}$.

Xákmok Kásek también confirmó los criterios expuestos en Sawhoyamaxa sobre el plazo para solicitar la recuperación de tierras tradicionales y las características que debe reunir la relación de los pueblos indígenas y tribales con dichas tierras para que el derecho de recuperación se mantenga vigente ${ }^{64}$. Insistiendo en un principio esbozado en Awas Tingni, el tribunal señaló que para garantizar el derecho de propiedad colectiva o comunal de los pueblos indígenas y tribales los estados parte del Pacto de San José de Costa Rica deben establecer recursos que aseguren un debido

60 Corte Interamericana de Derechos Humanos. 29 de marzo de 2006. Serie C No. 146 (voto razonado del juez García Ramírez). "Comunidad Indígena Sawhoyamaxa c. Paraguay", párrafo 11 .

Ver Corte IDH. 31 de agosto de 2001 (voto concurrente del juez García Ramírez). "Awas Tingni”, párrafo 14 .

61 Ver Corte IDH. 24 de agosto de 2010 (sentencia). "Xákmok Kásek”, párrafo 109.

62 Ver Corte IDH. 29 de marzo de 2006 (sentencia). "Sawhoyamaxa”, párrafo 128.

63 Ver Corte IDH. 24 de agosto de 2010 (sentencia). "Xákmok Kásek”, párrafo 109.

64 Ver Corte IDH. 24 de agosto de 2010 (sentencia). "Xákmok Kásek", párrafos 112-3.

Ver también CoRTe IDH. 29 de marzo de 2006 (sentencia). "Sawhoyamaxa”, párrafos 131-2.

En este punto, la sentencia también hace referencia a otras de sus decisiones judiciales.

Ver Corte IDH. 15 de junio de 2005 Serie C No. 124 (sentencia). "Comunidad Moiwana c. Surinam”, párrafo 133; y CorTe IDH. 17 de junio de 2005 (sentencia). "Yakye Axa”, párrafos $131-2,135$ y 137. 
proceso en la protección de sus tierras tradicionales ${ }^{65}$. En este sentido, la Corte reiteró:

[...] que ante tierras explotadas y productivas es responsabilidad del Estado, a través de los órganos nacionales competentes, determinar y tener en cuenta la especial relación de los miembros de la comunidad indígena reclamante con dicha tierra, al momento de decidir entre ambos derechos. De lo contrario, el derecho de reivindicación carecería de sentido y no ofrecería una posibilidad real de recuperar las tierras tradicionales. Limitar de esta forma la realización efectiva del derecho a la propiedad de los miembros de las comunidades indígenas no solo viola las obligaciones del Estado derivadas de las disposiciones de la Convención relativas al derecho a la propiedad, sino que también compromete la responsabilidad del Estado en relación a la garantía de un recurso efectivo y constituye un trato discriminatorio que produce exclusión social ${ }^{66}$.

La sentencia confirmó, asimismo, la vinculación existente entre el artículo 21 de la Convención Americana y lo dispuesto en el Convenio No 169 de la OIT, de donde surgiría la obligación estatal de:

[...] asegurar la participación efectiva de los miembros de la Comunidad, de conformidad con sus costumbres y tradiciones, en relación con todo plan o decisión que afecte sus tierras tradicionales y que pueda conllevar restricciones en el uso, goce y disfrute de dichas tierras, para así evitar que ello implique una denegación de su subsistencia como pueblo indígena ${ }^{67}$.

El juez Eduardo Vio redactó un voto concurrente en Xákmok Kásek, en el cual señaló que son los pueblos, y no sus miembros, los que deberían ser considerados parte lesionada y beneficiaria de las reparaciones que establezca la Corte en casos de propiedad colectiva indígena y tribal. Esto, conforme al derecho internacional de los derechos humanos ${ }^{68}$. En su opinión, si bien la sentencia del tribunal no se aleja de la posición adoptada en casos anteriores, Xákmok Kásek "parecería dejar margen para que en el

65 Ver Corte IDH. 24 de agosto de 2010 (sentencia). "Xákmok Kásek", párrafo 142.

Ver también CoRTe IDH. 31 de agosto de 2001 (sentencia). "Awas Tingni”, párrafos 137-9; Corte IDH. 17 de junio de 2005 (sentencia). "Yakye Axa", párrafo 96; y Corte IDH. 29 de marzo de 2006 (sentencia). "Sawhoyamaxa", párrafo 108.

66 Corte IDH. 24 de agosto de 2010 (sentencia). "Xákmok Kásek", párrafo 149.

67 Corte IDH. 24 de agosto de 2010 (sentencia). "Xákmok Kásek", párrafo 157. Ver Corte IDH. 28 de noviembre de 2007 (sentencia). "Saramaka”, párrafo 129.

68 Ver Corte Interamericana De Derechos Humanos. 24 de agosto de 2010. Serie C No. 214 (voto concurrente del juez Vio Grossi). "Comunidad Indígena Xákmok Kásek c. Paraguay", párrafos 2-27. 
futuro pudiese disponer de la posibilidad de adoptar [una] nueva aproximación en la materia" ${ }^{69}$.

\section{4) SALVAGUARDANDO LA SUBSISTENCIA DE UN PUEBLO}

No solo los pueblos indígenas tienen un derecho de propiedad comunal sobre sus tierras ancestrales y los recursos naturales asociados a estas -también lo tienen los pueblos tribales. Así se desprende de Moiwana, Pueblo Saramaka (2007) y, más recientemente, Comunidades afrodescendientes desplazadas de la cuenca del río Cacarica (Operación Génesis) (2013). La doctrina internacional ha comentado extensamente los dos primeros casos, llevados al tribunal por la Comisión Interamericana ${ }^{70}$. Tanto en Moiwana como en Saramaka, la Comisión alegó que el Estado demandado no respetó el derecho de propiedad colectiva de comunidades maroon conformadas por afrodescendientes de esclavos traídos a la fuerza a Sudamérica durante la colonización europea, que escaparon a sectores apartados y despoblados de la entonces Guayana Holandesa ${ }^{71}$.

Mientras en Moiwana la Comisión Interamericana alegó que los miembros de la comunidad N'djuka se veían imposibilitados de retomar su estilo de vida tradicional, como consecuencia del comportamiento del Estado demandado, en Saramaka la Comisión lo acusó de no reconocer el derecho de propiedad colectiva de la comunidad maroon de ese nombre que habita la región superior del río Surinam ${ }^{72}$. Al igual que los N'djuka de Moiwana, los Saramaka no son indígenas al sector donde han vivido desde que sus antepasados escaparon de la esclavitud ${ }^{73}$. Por sus caracterís-

69 Corte IDH. 24 de agosto de 2010 (voto concurrente del juez Vio Grossi). "Xákmok Kásek", párrafo 9.

70 Ver e.g. Brunner, Lisl (2008). "The Rise of Peoples' Rights in the Americas: The Saramaka People Decision of the Inter-American Court of Human Rights". Chinese Journal of International Law, Vol. 7 No 3, pp. 699-711; Orellana, Marcos (2008). "Saramaka People v. Suriname”. American Journal of International Law, Vol. 102 No 4, pp. 841-7; y RiverA Juaristi, Franciso, y Rinaldi, Karine (2008). "Pueblo Saramaka vs. Surinam: el derecho a la supervivencia de los pueblos indígenas y tribales como pueblos". Revista CEJIL, Vol. 3 No 4, pp. 80-96.

Respecto a Operación Génesis, ver López Escarcena, Sebastián (2016). "Operación Génesis: reflexiones en torno a la propiedad indígena y tribal”. Estudios Socio-Jurídicos, Vol. 18 No 1, pp. 136-68.

71 Ver Corte IDH. 15 de junio de 2005 (sentencia). "Moiwana”, párrafos 1- 3 y 86; y Corte IDH. 28 de noviembre de 2007 (sentencia). "Saramaka”, párrafos 1-4 y 78-86.

72 Ver Corte IDH. 15 de junio de 2005 (sentencia). "Moiwana”, párrafo 3; y Corte IDH. 28 de noviembre de 2007 (sentencia). "Saramaka”, párrafos 2 y 80.

73 Ver CoRte IDH. 28 de noviembre de 2007 (sentencia). "Saramaka”, párrafo 79.

Ver ibid., párrafos 80-3. 
ticas sociales, culturales y económicas, la Corte consideró a la comunidad Saramaka como un pueblo tribal, "particularmente gracias a la relación especial existente con sus territorios ancestrales, y porque se regulan ellos mismos, al menos en forma parcial, a través de sus propias normas, costumbres y tradiciones"74. Como tal, agregó el tribunal, Surinam tiene la obligación de adoptar medidas especiales que garanticen el pleno ejercicio de sus derechos, en especial el de propiedad "a fin de garantizar su supervivencia física y cultural"75.

En sus considerandos sobre el artículo 21 del Pacto de San José de Costa Rica, la Corte Interamericana confirmó que la interpretación de este precepto debe realizarse a partir de lo dispuesto en el Convenio No 169 de la OIT ${ }^{76}$. Esto, a pesar que Surinam no es parte de este tratado ${ }^{77}$. Para tal efecto, el tribunal interpretó el artículo 21 conforme al artículo 29.b de la Convención Americana sobre Derechos Humanos. Vale decir, de manera que no se limite el goce y ejercicio de los derechos reconocidos por Surinam en otros tratados, según han sido interpretados por los órganos destinados a supervisar el cumplimiento de dichos tratados, como el Comité de Derechos Económicos, Sociales y Culturales ${ }^{78}$. De acuerdo a la Corte, la falta de claridad respecto del sistema de posesión de tierras de la comunidad Saramaka, especialmente acerca de quienes son sus titulares, no constituye un obstáculo insuperable para el Estado demandado, quien tiene la obligación de consultar con los integrantes de la comunidad sobre este asunto ${ }^{79}$. Debido a que el marco legal surinamés únicamente le otorgaba a los integrantes de la comunidad Saramaka un

74 CoRTe IDH. 28 de noviembre de 2007 (sentencia). "Saramaka”, párrafo 84.

75 Corte IDH. 28 de noviembre de 2007 (sentencia). "Saramaka”, párrafo 85.

Ver ibid., párrafo $86 \& 96$.

El tribunal no solo fundamentó esta afirmación en Moiwana, sino que también en la jurisprudencia de la Corte Europea de Derechos Humanos.

Ver CoRTe IDH. 15 de junio de 2005 (sentencia). "Moiwana”, párrafos 132-4.

Ver también Corte Europea de Derechos Humanos. 27 de mayo de 2004 (sentencia). "James Connors c. Reino Unido", párrafo 84.

76 Ver Corte IDH. 28 de noviembre de 2007 (sentencia). "Saramaka”, párrafo 92.

Ver también Corte IDH. 17 de junio de 2005 (sentencia). "Yakye Axa”, párrafos 126-31, 135-7 \&143-51; y Corte IDH. 29 de marzo de 2006 (sentencia). "Sawhoyamaxa”, párrafos 117 y 119.

77 La información relativa a la ratificación del Convenio No 169 de la OIT está disponible en http://www.ilo.org/dyn/normlex/es/f?p=NORMLEXPUB:1 1300:0::NO:11300:P11300_ INSTRUMENT_ID:312314:NO [visitado el 15/3/2015].

78 Corte IDH. 28 de noviembre de 2007 (sentencia). "Saramaka”, párrafo 93.

Ver ibid., párrafos 94-6.

Cf. Pasqualucci (2009). "International Indigenous...”, pp. 65-8 ; y Rinaldi (2009): “Le droit des populations autochtones et tribales...”, pp. 233-4.

79 Ver Corte IDH. 28 de noviembre de 2007 (sentencia). "Saramaka”, párrafo 101. 
privilegio para usar la tierra, que no garantizaba el derecho de propiedad sobre sus territorios frente a interferencias del Estado o de terceros, la Corte declaró:

[...] los integrantes de pueblos indígenas y tribales deben obtener el título de su territorio a fin de garantizar el uso y goce permanente de dicha tierra. Este título debe ser reconocido y respetado, no solo en la práctica, sino que en el derecho, a fin de salvaguardar su certeza jurídica. A fin de obtener dicho título, el territorio que los miembros del pueblo Saramaka han usado y ocupado tradicionalmente debe ser primero demarcado y delimitado, a través de consultas realizadas con dicho pueblo y con los pueblos vecinos ${ }^{80}$.

Al no reconocer el derecho de propiedad colectiva de los miembros del pueblo Saramaka, la Corte resolvió que el Estado demandado incumplió el artículo 21 en su perjuicio ${ }^{81}$. Habiendo hecho esta constatación, el tribunal se abocó a determinar el alcance del derecho de propiedad sobre el territorio tradicional de los Saramaka y de las obligaciones correspondientes de Surinam. Insistiendo en que "la subsistencia cultural y económica de los pueblos indígenas y tribales [...] depende del acceso y el uso a los recursos naturales de su territorio", la Corte señaló que el artículo 21 de la Convención Americana protege estos, en la medida que estén ubicados en dichos territorios y los hayan usado tradicionalmente ${ }^{82}$. Aun cuando el derecho a los recursos naturales ya había sido reconocido en Yakye Axa, es en Saramaka donde el tribunal realmente lo desarrolla ${ }^{83}$. De acuerdo a esta sentencia, los pueblos indígenas y tribales no solo son titulares de sus tierras y territorios, sino que de los recursos naturales que allí encuentran y que han utilizado de esta manera ${ }^{84}$. Si bien de la lectura de estos párrafos se desprende que los únicos recursos naturales cubiertos convencionalmente son los que el pueblo respectivo ha usado en forma

80 Corte IDH. 28 de noviembre de 2007 (sentencia). "Saramaka”, párrafo 115.

La Corte hizo mención a Awas Tingni, Moiwana y Yakye Axa.

Ver Corte IDH. 31 de agosto de 2001 (sentencia). "Awas Tingni”, párrafo 153; Corte IDH. 15 de junio de 2005 (sentencia). "Moiwana”, párrafo 209; y CorTe IDH. 17 de junio de 2005 (sentencia). "Yakye Axa", párrafos 143 y 215.

81 CoRTe IDH. 28 de noviembre de 2007 (sentencia). "Saramaka”, párrafos 116 y 214.

82 Corte IDH. 28 de noviembre de 2007 (sentencia). "Saramaka”, párrafo 120.

Ver Corte IDH. 17 de junio de 2005 (sentencia). "Yakye Axa”, párrafos 131, 135-7; y Corte IDH. 29 de marzo de 2006 (sentencia). "Sawhoyamaxa”, párrafo 118-9 y 121.

83 Ver Corte IDH. 17 de junio de 2005 (sentencia). "Yakye Axa”, párrafo 137.

Ver también Rinaldi (2009): "Le droit des populations autochtones et tribales...”, pp. 231 3; y Ruiz Chiriboga y Donoso (2014): "Pueblos indígenas y la Corte Interamericana...”, pp. 982-3.

84 Ver CoRte IDH. 28 de noviembre de 2007 (sentencia). "Saramaka”, párrafos 121-2. 
tradicional, más adelante la misma sentencia agregó que el artículo 21 también protege los recursos naturales de los territorios indígenas y tribales que los miembros del pueblo respectivo no han usado tradicionalmente, "pero que su extracción afectaría, inevitablemente, otros recursos que son vitales para su modo de vida" ${ }^{\circ 5}$.

En relación al otorgamiento de concesiones de exploración y explotación de recursos naturales, Saramaka reiteró que la protección del artículo 21 no es absoluta, permitiendo la limitación y restricción del derecho de propiedad colectiva indígena y tribal, siempre que la medida respectiva satisfaga las condiciones de legalidad, necesidad, proporcionalidad e interés público, ya mencionados en Yakye Axa y Sawhoyamaxa, a los que ahora sumó un nuevo requisito, confirmado más tarde en Pueblo indígena Kichwa de Sarayaku (2012), Comunidad Garifuna Triunfo de la Cruz (2015), y Kaliña y Lokono: que la limitación o restricción no implique una denegación de su subsistencia como pueblo indígena o tribal ${ }^{86}$. Para garantizar que una concesión u otra medida que limite o restrinja este derecho de propiedad colectiva no implique una denegación de la subsistencia del pueblo correspondiente, el Estado debe cumplir tres salvaguardas consistentes en asegurar: primero, la participación efectiva de los miembros de la comunidad indígena o tribal, de conformidad con sus costumbres y tradiciones; segundo, que estos se "beneficien razonablemente" del proyecto que se realice dentro de su territorio; y tercero, que no se adoptará ninguna medida dentro de su territorio sin que "entidades independientes y técnicamente capaces" realicen un "estudio previo de impacto social y ambiental”, bajo supervisión estatal ${ }^{87}$. De acuerdo a la Corte, estas salva-

85 Ver Corte IDH. 28 de noviembre de 2007 (sentencia). "Saramaka”, párrafo 155.

Cf. Pasqualucci (2009). "International Indigenous...", pp. 80-1 \& 97; y RodríguezPiñero (2013): “El impacto internacional...", pp. 179-81.

86 Ver Corte IDH. 28 de noviembre de 2007 (sentencia). "Saramaka”, párrafos 127-8.

Ver también Corte IDH. 17 de junio de 2005 (sentencia). "Yakye Axa”, párrafos 144-5; Corte IDH. 29 de marzo de 2006 (sentencia). "Sawhoyamaxa", párrafo 138; Corte IDH. 27 de junio de 2012 (sentencia). "Kichwa de Sarayaku", párrafo 156; Corte IDH. 8 de octubre de 2015 (sentencia). "Garífuna Triunfo de la Cruz", párrafo 155; y Corte IDH. 25 de noviembre de 2015 (sentencia). "Kalińa y Lokono”, párrafos 155 \& 201.

Respecto del conflicto entre la propiedad colectiva indígena o tribal y la propiedad individual particular, la Corte confirmó en Saramaka los criterios expuestos en Yakye Axa y Sawhoyamaxa.

Ver Corte IDH. 28 de noviembre de 2007 (sentencia). "Saramaka”, párrafo 157.

Ver también CoRTe IDH. 17 de junio de 2005 (sentencia). "Yakye Axa”, párrafos 144-5; y Corte IDH. 29 de marzo de 2006 (sentencia). "Sawhoyamaxa”, párrafo 138.

87 Corte IDH. 28 de noviembre de 2007 (sentencia). "Saramaka”, párrafo 129.

Ver ibid., párrafo 143.

Ver también Corte Interamericana de Derechos Humanos. 12 de agosto de 2008. Serie C No. 185 (interpretación). "Pueblo Saramaka c. Surinam", párrafos 15, 17-9 y 22; CorTE 
guardas son consistentes con el artículo 32 de la Declaración de la ONU sobre los Derechos de los Pueblos Indígenas ${ }^{88}$.

Utilizando criterios que serán después reiterados en Kichwa de Sarayaku, Comunidad Garifuna de Punta Piedra (2015), Garifuna Triunfo de la Cruz, y Kaliña y Lokono, la Corte explicó que el deber de consulta implica una comunicación constante entre las partes, que ponga en conocimiento de los miembros del pueblo indígena o tribal los posibles riesgos del plan de desarrollo o inversión proyectado. En otras palabras, la consulta tiene que realizarse de buena fe, a través de procedimientos que tengan en cuenta la cultura indígena o tribal correspondiente y con el fin llegar a un acuerdo, en todas las etapas de planificación y ejecución del proyecto ${ }^{89}$. A continuación, la sentencia agregó un requisito adicional a la consulta, para los proyectos a gran escala que puedan tener un impacto relevante en el territorio del pueblo indígena o tribal: obtener su consentimiento "libre, previo e informado", según sus costumbres y tradiciones ${ }^{90}$. La Corte fundamentó esta aseveración en un informe de Rodolfo Stavenhagen, relator especial de la ONU sobre la situación de los derechos humanos y las libertades fundamentales de los indígenas ${ }^{91}$.

IDH. 27 de junio de 2012 (sentencia). "Kichwa de Sarayaku”, párrafo 157; y CorTe IDH. 8 de octubre de 2015 (sentencia). "Garífuna Triunfo de la Cruz", párrafos 156 y 179.

Ver CoRTe IDH. 28 de noviembre de 2007 (sentencia). "Saramaka", párrafo 131.

Ver ibid., párrafo 130.

89 Ver Corte IDH. 28 de noviembre de 2007 (sentencia). "Saramaka”, párrafo 133.

Ver también Corte IDH. 27 de junio de 2012 (sentencia). "Kichwa de Sarayaku”, párrafos 177-82; Corte IDH. 8 de octubre de 2015 (sentencia). "Garífuna de Punta Piedra", párrafos 216-8; Corte IDH. 8 de octubre de 2015 (sentencia). "Garífuna Triunfo de la Cruz", párrafos 158-60; y CoRTe IDH. 25 de noviembre de 2015 (sentencia). "Kaliña y Lokono”, párrafos 201-3.

Ver Rodríguez-Piñero (2013): pp. 186-8.

90 Corte IDH. 28 de noviembre de 2007 (sentencia). "Saramaka”, párrafos 134 \& 137. Ver CoRTe IDH. 12 de agosto de 2008 (interpretación). "Saramaka”, párrafo 17.

Ver tambien Rinaldi (2009): “Le droit des populations autochtones et tribales...”, pp. 23941; Olivares (2013). "Indigenous Peoples' Rights...”, p. 206; Gonza, Alejandra (2014): "Artículo 21. Derecho a la propiedad privada". En STEIner, Christian, y Uribe, Patricia (eds.): Convención Americana sobre Derechos Humanos: comentario. La Paz: Fundación Konrad Adenauer, pp. 503-30, en pp. 527-8; y Ruíz Chiriboga y Donoso (2014): "Pueblos indígenas y la Corte Interamericana...”, pp. 990-3.

91 Ver Corte IDH. 28 de noviembre de 2007 (sentencia). “Saramaka”, párrafo 135.

Ver ibid., párrafo 136.

La sentencia se refirió a su informe del 21 de enero de 2003, E/CN.4/2003/90, párrafos 2 \& 66 . El tribunal hizo mención, asimismo, a un informe del Comité de la ONU para la Eliminación de la Discriminación Racial, órgano de tratado establecido conforme a la Convención Internacional sobre la Eliminación de todas las Formas de Discriminación Racial de 1965. Este tratado está vigente desde 1969, y se encuentra disponible en: http://www.ohchr.org/ SP/ProfessionalInterest/Pages/CERD.aspx [visitado el 15/3/2015]. 
En opinión del tribunal, compartir razonablemente los beneficios del proyecto con el pueblo indígena o tribal es una obligación "inherente al derecho de indemnización reconocido en el artículo 21.2 de la Convención" ${ }^{2}$. La Corte justificó esta declaración no solo en el artículo 15.2 del Convenio No 169 de la OIT y el artículo 32.2 de la Declaración de la ONU sobre los Derechos de los Pueblos Indígenas, además del informe de Rodolfo Stavenhagen ya citado, sino en el texto del propio artículo 21 del Pacto de San José de Costa Rica ${ }^{93}$. Equiparando la participación razonable en los beneficios de un proyecto de desarrollo o inversión en territorio indígena o tribal con la indemnización debida por una expropiación indirecta, el tribunal dijo:

[...] el derecho a recibir el pago de una indemnización conforme al artículo 21.2 de la Convención se extiende no solo a la total privación de un título de propiedad por medio de una expropiación por parte del Estado, por ejemplo, sino que también comprende la privación del uso y goce regular de dicha propiedad. En el presente caso, el derecho a obtener el pago de una 'indemnización justa' conforme al artículo 21.2 de la Convención se traduce en el derecho de los miembros del pueblo Saramaka a participar, en forma razonable, de los beneficios derivados de la restricción o privación del derecho al uso y goce de sus tierras tradicionales y de aquellos recursos naturales necesarios para su supervivencia ${ }^{94}$.

Empleando los criterios anteriormente expuestos para evaluar el comportamiento de Surinam, el tribunal resolvió que las concesiones madereras y mineras auríferas otorgadas en los territorios de los Saramaka no cumplieron con los requisitos de participación efectiva, beneficios compartidos y estudio de impacto ambiental previo, violando así el artículo 21 en perjuicio de los integrantes de la comunidad maroon ${ }^{95}$.

En Saramaka, la Corte señaló que el reconocimiento de la personalidad jurídica a través de medidas legislativas o de otra naturaleza, previa consulta al pueblo indígena o tribal correspondiente, "es un modo, aunque no sea el único" de garantizarle a estas comunidades que podrán ejercer "en su conjunto" el derecho de propiedad colectiva, brindándoles una

92 Conte IDH. 28 de noviembre de 2007 (sentencia). "Saramaka”, párrafo 138.

93 Ver Corte IDH. 28 de noviembre de 2007 (sentencia). “Saramaka”, párrafo 139.

Ver ibid., párrafo 138 y 140.

La sentencia volvió a referirse, además, al informe del Comité de la ONU para la Eliminación de la Discriminación Racial citado anteriormente.

94 Corte IDH. 28 de noviembre de 2007 (sentencia). "Saramaka”, párrafo 139.

95 Ver Conte IDH. 28 de noviembre de 2007 (sentencia). "Saramaka”, párrafos 146, 154-6, $158 \& 214$.

Ver ibid., párrafo 143, 147-8, 153. 
igual protección judicial contra toda violación de este derecho ${ }^{96}$. Según el tribunal, la falta de reconocimiento de la personalidad jurídica de la comunidad maroon de Saramaka constituyó un incumplimiento del artículo 3 de la Convención Americana97. Puesto que la legislación interna del Estado demandado no ofreció "recursos legales adecuados y eficaces para proteger a los miembros del pueblo Saramaka contra actos que violan su derecho a la propiedad", el tribunal condenó a Surinam por violar el artículo 25 del Pacto de San José de Costa Rica, que establece el derecho a protección judicial ${ }^{98}$.

En su decisión sobre interpretación de la sentencia en Saramaka, la Corte desarrolló con más detalle en qué consiste la obligación estatal de realizar un estudio de impacto ambiental y social. Para el tribunal, estos estudios "sirven para evaluar el posible daño o impacto que un proyecto de desarrollo o inversión puede tener sobre la propiedad y comunidad en cuestión"99. De ahí que su fin no solo sea objetivar el posible efecto del proyecto en cuestión sobre la tierra y las personas, sino también asegurar que los integrantes de un pueblo indígena o tribal conozcan sus riesgos potenciales, incluidos los ambientales y de salubridad, para que puedan aceptarlo de manera voluntaria e informada ${ }^{100}$. Como explicó la Corte, los estudios de impacto ambiental y social deben realizarse "por entidades independientes y técnicamente capacitadas", de acuerdo "a los estándares internacionales y buenas prácticas al respecto", respetando "las tradiciones y cultura" del pueblo indígena o tribal que se trate, y en forma previa al otorgamiento de la concesión respectiva ${ }^{101}$. El tribunal destacó en esta decisión judicial que uno de los factores a tratar en dicho estudio debiera ser "el impacto acumulado que han generado los proyectos existentes y los que vayan a generar los proyectos que hayan sido propuestos", a fin de poder concluir si sus efectos "pueden poner en peligro la supervivencia de

96 Ver Corte IDH. 28 de noviembre de 2007 (sentencia). "Saramaka”, párrafo 171. Ver ibid., párrafos 167-9 y 172-4.

Ver también Corte IDH. 29 de marzo de 2006 (sentencia). "Sawhoyamaxa”, párrafo 189.

97 Ver CoRTe IDH. 28 de noviembre de 2007 (sentencia). "Saramaka”, párrafos 173-5.

El art. 3 de la Convención Americana consagra el derecho al reconocimiento de la personalidad jurídica.

Al respecto ver Dhommeaux (2009): “Les communautés autochtones et tribales...", pp. 201-2; y Salmón (2011): Jurisprudencia de la Corte..., pp. 230-3.

98 Corte IDH. 28 de noviembre de 2007 (sentencia). "Saramaka", párrafo 185.

Ver ibid, párrafos 178-9 \& 182-4.

Ver también CoRTe IDH. 31 de agosto de 2001 (sentencia). "Awas Tingni”, párrafos 137-9;

Corte IDH. 17 de junio de 2005 (sentencia). "Yakye Axa”, párrafo 96; y Corte IDH. 29

de marzo de 2006 (sentencia). "Sawhoyamaxa", párrafo 108.

99 Corte IDH. 12 de agosto de 2008 (interpretación). "Saramaka”, párrafo 40.

100 Ver CoRTe IDH. 12 de agosto de 2008 (interpretación). "Saramaka”, párrafo 40.

101 Corte IDH. 12 de agosto de 2008 (interpretación). "Saramaka”, párrafo 41. 
los pueblos indígenas o tribales"102. Para la Corte, este último requisito sería el principal criterio en virtud del cual se deben analizar los resultados de los estudios de impacto ambiental y social ${ }^{103}$.

\section{5) El DERECHO DE CONSULTA Y EL ARTÍCULO 21}

Una de las sentencias más importantes dictadas por la Corte Interamericana contra un estado por violación del derecho de propiedad colectiva de los pueblos indígenas es Kichwa de Sarayaku ${ }^{104}$. En este caso, la Comisión demandó a Ecuador por haber otorgado un permiso de exploración y explotación a una empresa petrolífera privada en la década de 1990, sin haber consultado previamente a las comunidades indígenas que habitaban el territorio sobre el cual recayó dicho permiso, y sin haber obtenido el consentimiento de los Kichwa de Sarayaku para la realización de actividades que afectaron sus derechos convencionales, incluyendo el de propiedad comunal reconocido y protegido por el artículo $21^{105}$. Kichwa de Sarayaku no es solo el primer caso contencioso en la historia de la Corte Interamericana en que una delegación de sus jueces realizó una diligencia de visita al lugar de los hechos, sino que es la primera disputa en su jurisprudencia sobre propiedad colectiva indígena y tribal en que no se puso en duda el derecho comunal al territorio, plenamente reconocido por Ecuador en esta controversia ${ }^{106}$. Esto explica que el tribunal centrara su análisis en el derecho de consulta indígena y tribal consagrado en el artículo 21 de la Convención Americana.

En sus consideraciones, la Corte comenzó por destacar la importancia del acceso a los recursos naturales existentes en los territorios ancestra-

102 Corte IDH. 12 de agosto de 2008 (interpretación). "Saramaka”, párrafo 41.

103 Ver CorTe IDH. 12 de agosto de 2008 (interpretación). “Saramaka”, párrafo 42.

104 Operación Génesis se refiere a un pueblo tribal.

105 Ver Corte IDH. 27 de junio de 2012 (sentencia). "Kichwa de Sarayaku”, párrafos 1-4.

106 Ver Corte IDH. 27 de junio de 2012 (sentencia). "Kichwa de Sarayaku”, párrafos 18-21, $124 \& 149$.

La diligencia in situ del tribunal se volvería a ordenar en los casos Garifuna de Punta Piedra, Garifuna Triunfo de la Cruz y Kaliña y Lokono.

Ver en general Corte IDH. 8 de octubre de 2015 (sentencia). "Garífuna de Punta Piedra”; Corte IDH. 8 de octubre de 2015 (sentencia). "Garífuna Triunfo de la Cruz"; y Corte IDH. 25 de noviembre de 2015 (sentencia). "Kaliña y Lokono".

El juez Humberto Sierra se refirió a la importancia de esta diligencia de visita al lugar de los hechos, en su voto concurrente en Garifuna Triunfo de la Cruz.

Ver Corte Interamericana de Derechos Humanos. 8 de octubre de 2015. Serie C No. 305 (voto concurrente del juez Sierra Porto). "Comunidad Garífuna Triunfo de la Cruz y sus miembros c. Honduras", párrafos 11-9. 
les y su control por las comunidades indígenas y tribales, a fin de garantizar la sobrevivencia del pueblo respectivo ${ }^{107}$. Aplicando los criterios para determinar la relación de los pueblos indígenas y tribales con sus tierras tradicionales, expuestos en Sawhoyamaxa y reiterados en Xákmok Kásek, el tribunal pudo constatar el profundo lazo que la comunidad Kichwa de Sarayaku ha mantenido con su territorio ${ }^{108}$. A continuación, la Corte reafirmó que las pautas para establecer cuándo es admisible una limitación o restricción a la propiedad colectiva indígena y tribal ya no eran cuatro, como en Yakye Axa y Sawhoyamaxa. Además de la legalidad, necesidad, proporcionalidad y utilidad pública requeridas por estas sentencias, el tribunal corroboró la quinta pauta introducida en Saramaka: que la limitación o restricción no implique una denegación de la subsistencia del pueblo indígena o tribal ${ }^{109}$. Esta última pauta exige que el Estado cumpla con ciertas salvaguardas al momento de autorizar la exploración y explotación de recursos naturales en territorios ancestrales, las cuales consisten en:

i) efectuar un proceso adecuado y participativo que garantice su derecho a la consulta, en particular, entre otros supuestos, en casos de planes de desarrollo o de inversión a gran escala; ii) la realización de un estudio de impacto ambiental; y iii) en su caso, compartir razonablemente los beneficios que se produzcan de la explotación de los recursos naturales (como una forma de justa indemnización exigida por el artículo 21 de la Convención), según lo que la propia comunidad determine y resuelva respecto de quienes serían los beneficiarios de tal compensación según sus costumbres y tradiciones ${ }^{110}$.

En Kichwa de Sarayaku, la Corte se explayó en el deber estatal de consulta, como no lo había hecho antes en su jurisprudencia sobre propiedad comunal indígena y tribal. Con este objeto, la sentencia volvió a vincular el artículo 21 del Pacto de San José de Costa Rica con el Convenio No 169 de la OIT, y destacó la relevancia del derecho comparado en

\footnotetext{
107 Ver Corte IDH. 27 de junio de 2012 (sentencia). “Kichwa de Sarayaku”, párrafos 145-7.

108 Ver Conte IDH. 27 de junio de 2012 (sentencia). "Kichwa de Sarayaku”, párrafos 148-9 \& 155.

Ver también Corte IDH. 29 de marzo de 2006 (sentencia). "Sawhoyamaxa”, párrafos 1312; y Corte IDH. 24 de agosto de 2010 (sentencia). "Xákmok Kásek”, párrafo 113.

109 Ver Corte IDH. 27 de junio de 2012 (sentencia). "Kichwa de Sarayaku”, párrafos 156-7. Ver también Corte IDH. 17 de junio de 2005 (sentencia). "Yakye Axa”, párrafos 144-5; Corte IDH. 29 de marzo de 2006 (sentencia). "Sawhoyamaxa", párrafo 138; y Corte IDH. 28 de noviembre de 2007 (sentencia). "Saramaka”, párrafos 128-9.

La Corte citó, asimismo, la decisión sobre interpretación de la sentencia en Saramaka.

Ver Corte IDH. 12 de agosto de 2008 (interpretación). "Saramaka”, párrafos 25-7.

110 Corte IDH. 27 de junio de 2012 (sentencia). "Kichwa de Sarayaku”, párrafo 157.
} 
la interpretación de dicha disposición ${ }^{111}$. Como preámbulo a su estudio iuscomparativo, el tribunal citó la noción de pueblos tribales que contempla el tratado de la OIT, omitiendo la definición de pueblos indígenas que contiene dicho acuerdo internacional. De esta manera, hizo mención a aquellos pueblos cuyas condiciones sociales, culturales y económicas les distingan de otros sectores de la colectividad nacional, y que estén regidos total o parcialmente por sus propias costumbres o tradiciones o por una legislación especial", pero no a aquellos:

[...] considerados indígenas por el hecho de descender de poblaciones que habitaban en el país o en una región geográfica a la que pertenece el país en la época de la conquista o la colonización o del establecimiento de las actuales fronteras estatales y que, cualquiera que sea su situación jurídica, conservan todas sus propias instituciones sociales, económicas, culturales y políticas, o parte de ellas ${ }^{112}$.

La Corte se refirió expresamente a los derechos de los pueblos indígenas y tribales sobre sus tierras y territorios recogidos en los artículos 13 a 19 del Convenio No 169 de la OIT, así como a la regulación del derecho de "consulta previa[,] libre e informada" que ofrecen los artículos 6, 15, 17, 22, 27 y 28 del mismo tratado ${ }^{113}$. Con apoyo en el tratado de la OIT y la legislación y/o jurisprudencia judicial interna de Argentina, Belice, Bolivia, Brasil, Canadá, Chile, Colombia, Costa Rica, Ecuador, Guatemala, EE.UU., México, Nueva Zelanda, Nicaragua, Paraguay, Perú y Venezuela, el tribunal concluyó que la obligación de consulta es un principio general del derecho internacional positivado convencionalmente, que debe hacerse efectivo toda vez que una medida estatal afecte los derechos de los pueblos indígenas y tribales reconocidos internacional o internamente, asegurando su participación en la decisión de aquellos asuntos en los que tengan interés, a través de procedimientos que: respeten las parti-

111 Ver Conte IDH. 27 de junio de 2012 (sentencia). "Kichwa de Sarayaku”, párrafos 159-61, 163-5 y 171.

Ver también CoRte IDH. 17 de junio de 2005 (sentencia). "Yakye Axa”, párrafos 126-31, 135-7 y 143-51; Corte IDH. 29 de marzo de 2006 (sentencia). "Sawhoyamaxa”, párrafos 117 y 119; Corte IDH. 28 de noviembre de 2007 (sentencia). "Saramaka”, párrafo 130; y Corte IDH. 24 de agosto de 2010 (sentencia). "Xákmok Kásek”, párrafo 157.

112 Art. 1.1 del Convenio No 169 de la OIT.

Ver Corte IDH. 27 de junio de 2012 (sentencia). "Kichwa de Sarayaku”, párrafo 163.

Sobre la indeterminación de las nociones de pueblo indígena y tribal, de sus tierras y territorios ancestrales y tradicionales, y de privaciones y limitaciones o restricciones a su derecho de propiedad, en la jurisprudencia de la Corte, ver en general López Escarcena (2016). "Operación Génesis...".

Art. 1.1 del Convenio No 169 de la OIT.

113 Ver Corte IDH. 27 de junio de 2012 (sentencia). "Kichwa de Sarayaku”, párrafo 163. 
cularidades de cada pueblo indígena o tribal; generen canales de diálogo sostenido y confiable con instituciones representativas de las comunidades involucradas; y se apliquen en todas las fases de planificación y ejecución de los proyectos que puedan afectar sus territorios ancestrales ${ }^{114}$. Según el tribunal, corresponde al Estado controlar y fiscalizar la aplicación de estos procedimientos, proveyendo "formas de tutela efectiva de este derecho [de consulta] por medio de los órganos judiciales correspondientes" 115 . Además de referencias al Convenio No 169 de la OIT y al derecho comparado, la Corte Interamericana mencionó los artículos 15.2, 17.2, 19, 30.2, 32.2, 36.2 y 38 de la Declaración de la ONU sobre los Derechos de los Pueblos Indígenas del 2007116. En Kichwa de Sarayaku, la Corte no mencionó la necesidad de obtener el consentimiento del pueblo respectivo para proyectos a gran escala que puedan tener un impacto relevante en su territorio, como antes lo hiciera en Sarayaku ${ }^{117}$.

114 Ver Corte IDH. 27 de junio de 2012 (sentencia). "Kichwa de Sarayaku”, párrafos 159, 161 y $163-7$.

115 Corte IDH. 27 de junio de 2012 (sentencia). "Kichwa de Sarayaku", párrafo 167.

116 Ver Corte IDH. 27 de junio de 2012 (sentencia). "Kichwa de Sarayaku", párrafo 167. La Declaración de la ONU sobre los Derechos de los Pueblos Indígenas fue aprobada por la Asamblea General de esta organización internacional en su Res. 61/295 de 2007, disponible en http://www.un.org/esa/socdev/unpfii/documents/DRIPS_es.pdf [visitado el 15/3/2015]. Sobre esta declaración de la ONU ver BeNGOA (2007): La emergencia indígena en América Latina, pp. 275-81, 287-91 y 295-8; Wiessner, Siegfried (2008). "Indigenous Sovereignty: A Reassessment in Light of the UN Declaration on the Rights of Indigenous People". Vanderbilt Journal of Transnational Law, Vol. $41 \mathrm{~N}^{\circ}$ 4, pp. 1141-76, en pp. 1159-66; ZALAQUETT, José (2008). "La Declaración de Naciones Unidas sobre Derechos de los Pueblos Indígenas". Anuario de Derechos Humanos, 4, pp. 139-48; Barelli, Mauro (2009). "The Role of Soft Law in the International Legal System: the Case of the United Nations Declaration on the Rights of Indigenous Peoples". International \& Comparative Law Quarterly, Vol. 58, pp. 957-83; Xanthaki (2009). "Indigenous Rights in...", pp. 29-32 y 34-7; UN Permanent Forum on Indigenous Peoples (2009): State of the World's..., pp. 197-9; Xanthaki (2010): Indigenous Rights and..., pp. 102-27; MARCelli (2011): Los derechos..., pp. 102-115; Mereminskaya, Elina (2011). "El Convenio 169 de la OIT sobre pueblos indígenas y tribales: derecho internacional y experiencias comparadas". Estudios Públicos, Vol. 121, pp. 213 76, en pp. 225-8; Sieder (2011): "Pueblos indígenas...", pp. 309-12; GAETE, Lucía (2012). "El Convenio $\mathrm{N}^{\circ} 169$. Un análisis de sus categorías problemáticas a la luz de su historia normativa”. Ius et Praxis, Vol. 18 N² 2, pp. 77-124, en pp. 88-94; Hervé y Pérez (2012): "Adecuación de la legislación interna...", en pp. 32-7; y Olivares (2013). "Indigenous Peoples' Rights ...”, pp. 191-2.

Ver también Gómez del Prado, José Luis (2002): Pueblos indigenas. Normas internacionales y marcos nacionales. Bilbao: Publicaciones de la Universidad de Deusto, 122 pp., en pp. 3645; Thornberry (2002): Indigenous Peoples..., pp. 370-96; Hannum (2003): "Indigenous Rights.", pp. 89-90; EIDE (2006). "Rights of Indigenous Peoples...", pp. 159-67, 189-207 y 211-2; y Aguilar (2007): Dinámica internacional..., pp. 31-40 y 82-96.

117 Ver CoRTe IDH. 28 de noviembre de 2007 (sentencia). "Saramaka", párrafos 134 y 137; y CoRTe IDH. 12 de agosto de 2008 (interpretación). "Saramaka", párrafo 17.

Cf. Olivares (2013). "Indigenous Peoples' Rights...", p. 212-4. 
En virtud de las consideraciones anteriores, el tribunal evaluó el comportamiento de Ecuador de acuerdo a cinco preguntas: ¿fue previa la consulta?, ¿fue realizada de buena fe y con la finalidad de llegar a un acuerdo?, ¿fue adecuada y accesible?, ¿se realizó un estudio de impacto ambiental? y ¿fue informada? ${ }^{118}$. En esta parte de su sentencia, la Corte nuevamente se apoyó en diversas disposiciones del Convenio No 169 de la OIT y de la Declaración de la ONU sobre los Derechos de los Pueblos Indígenas, en criterios jurisprudenciales desarrollados en Saramaka, en principios jurídicos provenientes del derecho comparado, y en informes de Rodolfo Stavenhagen y James Anaya, relatores especiales de la ONU sobre la situación de los derechos humanos y las libertades fundamentales de los pueblos indígenas ${ }^{119}$. De esta forma, el tribunal resolvió que Ecuador incumplió la obligación de consulta, violando lo establecido en el artículo 21 de la Convención Americana sobre Derechos Humanos ${ }^{120}$. Esto, por cuanto el proyecto petrolero se empezó a ejecutar sin que el Estado demandado haya consultado a los Kichwa de Sarayaku en forma previa, de buena fe, con el fin de lograr un acuerdo, y de manera adecuada, accesible e informada ${ }^{121}$. Lo único que hubo fue una "socialización" del

118 Ver Corte IDH. 27 de junio de 2012 (sentencia). "Kichwa de Sarayaku", párrafos 176-9.

119 Ver Corte IDH. 27 de junio de 2012 (sentencia). "Kichwa de Sarayaku", párrafos 180-211. Ver también CoRTe IDH. 28 de noviembre de 2007 (sentencia). "Saramaka", párrafos 102, 129-31 y 134.

El tribunal también se refirió a la decisión sobre interpretación de la sentencia en Saramaka. Ver Corte IDH. 12 de agosto de 2008 (interpretación). "Saramaka", párrafos 40-1.

La Corte hizo mención a los artículos 6, 7.3, 12 y 15.2 del Convenio No 169 de la OIT y los artículos 19, 30.2, 32.2 y 36.2 de la Declaración de la ONU sobre los Derechos de los Pueblos Indígenas, además de la legislación y/o jurispridencia judicial interna de Bolivia, Colombia, Ecuador, EE.UU., Guatemala, México, Nicaragua, Perú y Venezuela. La sentencia se refirió, asimismo, a diversos informes de órganos de tratado establecidos en virtud del Convenio No 169 de la OIT.

Los informes de los relatores especiales sobre la situación de los derechos humanos y las libertades fundamentales de los pueblos indígenas que citó el tribunal son los del 15 de noviembre de 2007, A/HRC/6/15, párrafo 43, de Rodolfo Stavenhagen, y del 15 de julio de 2009, A/HRC/12/34, párrafos 53-5, y del 5 de octubre de 2009, A/HRC/12/34/Add.6, Apéndice A, párrafos 18-21, 23-5, 28, 31, 33 y 49-50, ambos de James Anaya.

Los informes de los relatores especiales de la ONU sobre la situación de los derechos humanos y las libertades fundamentales de los pueblos indígenas, Rodolfo Stavenhagen y James Anaya, así como de la actual relatora especial de la ONU sobre los derechos de los pueblos indígenas, Vicky Tauli-Corpuz, están disponibles en: http://ap.ohchr.org/documents/ dpage_s.aspx?m=73 [visitado el 15/3/2015].

Tanto Rodolfo Stavenhagen como James Anaya comparecieron en este caso como peritos.

Ver Corte IDH. 27 de junio de 2012 (sentencia). "Kichwa de Sarayaku”, párrafos 32, 34, $168,180,187$ y 297.

120 Ver Corte IDH. 27 de junio de 2012 (sentencia). "Kichwa de Sarayaku”, párrafos 211, 220,232 y 341.

121 Ver Corte IDH. 27 de junio de 2012 (sentencia). "Kichwa de Sarayaku", párrafos 184-5, $189,193-4,198-200,203$ y 207. 
proyecto o "búsqueda de entendimiento" con la comunidad indígena, por parte de la empresa privada ${ }^{122}$. Citando a Saramaka, la sentencia declaró:

Es necesario enfatizar que la obligación de consultar es responsabilidad del Estado, por lo que la planificación y realización del proceso de consulta no es un deber que pueda eludirse delegándolo en una empresa privada o en terceros, mucho menos en la misma empresa interesada en la explotación de los recursos en el territorio de la comunidad sujeto de la consulta ${ }^{123}$.

Desde esta perspectiva, la Corte señaló que el estudio de impacto ambiental efectuado por una entidad privada subcontratada por la empresa petrolera fue realizado sin la participación de la comunidad indígena, sin un control estricto posterior por órganos estatales de fiscalización, y sin tomar en cuenta "la incidencia social, espiritual y cultural que las actividades de desarrollo previstas podían tener sobre el Pueblo Sarayaku"124. Haciendo realidad lo adelantado por el juez Eduardo Vio en su voto concurrente en Xákmok Kásek, la Corte consideró al pueblo indígena mismo y no a sus miembros como parte lesionada y beneficiaria de las reparaciones dictadas por las violaciones al artículo 21 de Ecuador; algo que no había hecho hasta entonces en su jurisprudencia sobre propiedad colectiva $^{125}$.

A partir de su análisis del derecho de consulta, el tribunal reconoció en Kichwa de Sarayaku el carácter autónomo del derecho colectivo a la identidad cultural, calificándolo como instrumento de interpretación transversal de los otros derechos convencionales de los pueblos indígenas y tribales ${ }^{126}$. A este respecto, la sentencia citó el principio 22 de la Declaración de Río sobre el Medio Ambiente y el Desarrollo de 1992; los artículos 2.3 b), 4.1 y 5 del Convenio No 169 de la OIT, los artículos 3, $4,5,8,12.1,18,19,20,23,32,33$ y 34 de la Declaración de la ONU

\footnotetext{
122 Ver Corte IDH. 27 de junio de 2012 (sentencia). "Kichwa de Sarayaku”, párrafos 178, $188,200,203$ y 209-10.

123 Corte IDH. 27 de junio de 2012 (sentencia). "Kichwa de Sarayaku”, párrafo 187.

Ver Corte IDH. 28 de noviembre de 2007 (sentencia). "Saramaka”, párrafos 102, 129 y 131.

124 Corte IDH. 27 de junio de 2012 (sentencia). "Kichwa de Sarayaku”, párrafo 207. Ver ibid., párrafos 188 y 205-6.

125 Ver CoRTe IDH. 27 de junio de 2012 (sentencia). "Kichwa de Sarayaku”, párrafos 231, 284 y 341 .

Ver también Corte IDH. 24 de agosto de 2010 (voto concurrente del juez Vio Grossi). "Xákmok Kásek", párrafos 5-27.

126 Ver Corte IDH. 27 de junio de 2012 (sentencia). “Kichwa de Sarayaku”, párrafo 213. Ver ibid., párrafo 217.

Ver también Rodríguez-Piñero (2013): “El impacto internacional...”, pp. 171-3.
} 
sobre los Derechos de los Pueblos Indígenas; diversos instrumentos de la Organización de la ONU para la Educación, la Ciencia y la Cultura (UNESCO, por sus siglas en inglés); y la jurisprudencia de los sistemas europeo y africano de derechos humanos ${ }^{127}$. Para el tribunal, la falta de consulta a los Kichwa de Sarayaku afectó su identidad cultural ${ }^{128}$. Asimismo, al no contar Ecuador con un reglamento detallado que establezca con claridad el objeto y los sujetos de la consulta, además de cuándo debe procederse a esta, la Corte resolvió que incumplió la obligación de adoptar disposiciones de derecho interno del artículo 2 de la Convención Americana, en relación con las violaciones de los derechos de consulta, identidad cultural y propiedad colectiva ${ }^{129}$.

\section{6) AWAS TingNi, MoIWANA Y Cía}

Después de Kichwa de Sarayaku, la Corte ha condenado a Colombia, Panamá, Honduras y Surinam por violar el derecho de propiedad consagrado en el artículo 21 del Pacto de San José de Costa Rica, en los casos Operación Génesis, Pueblos indigenas Kuna de Madungandi y Emberá de Bayano (2014), Garifuna de Punta Piedra y Garifuna Triunfo de la Cruz, y Kaliña y Lokono, respectivamente. Los hechos por los cuales el tribunal condenó a Colombia en Operación Génesis se produjeron en el contexto del conflicto armado colombiano y constituyeron, ante todo, incumplimientos de otras disposiciones convencionales ${ }^{130}$. La responsabilidad internacional de Colombia se derivó de: las destrucciones y saqueos que acompañaron a

127 Ver Conte IDH. 27 de junio de 2012 (sentencia). "Kichwa de Sarayaku”, párrafos 214-7.

La Declaración de Río sobre el Medio Ambiente y el Desarrollo se acordó en la conferencia de la ONU del mismo nombre, también conocida como Cumbre para la Tierra, celebrada en 1992 en Río de Janeiro, Brasil. Está disponible en

http://www.un.org/spanish/esa/sustdev/agenda $21 /$ riodeclaration.htm [visitado el 15/3/2015].

Del sistema europeo de derechos humanos, la Corte citó los casos Chapman y Gorzelik.

Corte Europea de Derechos Humanos. 18 de enero de 2001 (sentencia). "Sally Chapman c. Reino Unido", párrafo 93; y Corte Europea de Derechos Humanos. 17 de febrero de 2004 (sentencia). "Jerzy Gorzelik y Otros c. Polonia”, párrafo 92.

Las jurisprudencia de la Corte Europea de Derechos Humanos está disponible en inglés o francés en: http://hudoc.echr.coe.int/sites/eng/Pages/search.aspx\# [visitado el 15/3/2015].

128 Ver Corte IDH. 27 de junio de 2012 (sentencia). "Kichwa de Sarayaku”, párrafo 220. Ver ibid., párrafos 218-9.

129 Ver Corte IDH. 27 de junio de 2012 (sentencia). "Kichwa de Sarayaku”, párrafos 221-7 \& 232.

130 Masacres de Ituango y Masacre de Santo Domingo también provienen del conflicto armado colombiano, y fueron mencionados por la Corte en Operación Génesis.

Ver CoRte IDH. 20 de noviembre de 2013 (sentencia). “Operación Génesis”, párrafos 34050 y 352 . 
la Operación Cacarica, realizada por las fuerzas paramilitares con la colaboración activa o pasiva del Estado colombiano, apenas iniciada la Operación Génesis que ejecutaron su ejército, la fuerza área y la armada en esa zona del noroeste de dicho país; el abandono en que quedaron los territorios de la comunidad de afrodescendientes que habitaban el área afectada por la mencionada operación paramilitar tras los desplazamientos forzados de sus miembros; y la explotación ilegal de sus recursos naturales efectuada por empresas privadas con el permiso o la tolerancia de Colombia ${ }^{131}$. Operación Génesis reiteró la protección de la propiedad tribal que había reconocido la Corte en Moiwana y Saramaka, insistiendo en los criterios jurisprudenciales allí expuestos, así como en Awas Tingni, Yakye Axa y Kichwa de Sarayaku ${ }^{132}$. No deja de llamar la atención que Operación Génesis no siguiera el principio reconocido por el propio tribunal el año anterior en Kichwa de Sarayaku, y considerara como parte lesionada y beneficiaria de las reparaciones correspondientes a los miembros de la comunidad de afrodescendientes desplazados del Cacarica y no al pueblo tribal mismo ${ }^{133}$. Este principio, adelantado por el juez Eduardo Vio en su voto concurrente de Xákmok Kásek, volvería a ser adoptado por la Corte en Kuna y Embará, pero solo a medias.

En este caso, aunque el tribunal reconoció expresamente que la parte lesionada eran las comunidades afectadas y sus miembros, solamente consideró a estos como beneficiarios de las reparaciones que ordenó, debido a que eran dichos integrantes las víctimas de las violaciones declaradas ${ }^{134}$. Meses antes que la Corte dictara su sentencia en Kuna y Emberá, el juez Eduardo Ferrer había recordado en su voto concurrente en Liakat Ali Alibux (2014) que el artículo 21 de la Convención Americana ha sido reiteradamente interpretado por el tribunal a partir de las disposiciones del Convenio $\mathrm{N}^{\circ} 169$ de la OIT, y la Corte había reiterado obiter dicta en su

Ver también Corte IDH. 1 de junio de 2006 (sentencia). "Masacres de Ituango"; y Corte IDH. 30 de noviembre de 2012 (sentencia). "Masacre de Santo Domingo".

Como en Operación Génesis, en Masacre Plan de Sánchez y Moiwana el tribunal condenó al Estado demandado por incumplir el artículo 21, a través de conductas constitutivas de violaciones a otros derechos protegidos por la Convención Americana, distintos al de propiedad.

Ver en general Corte IDH. 19 de noviembre 2004 (sentencia). "Masacre Plan de Sánchez"; y Corte IDH. 15 de junio de 2005 (sentencia). "Moiwana”.

131 Ver Conte IDH. 20 de noviembre de 2013 (sentencia). “Operación Génesis”, párrafos 3516,358 y 486.

132 Ver en general López Escarcena (2016). “Operación Génesis...”.

133 Ver CoRTe IDH. 20 de noviembre de 2013 (sentencia). “Operación Génesis”, párrafos 353, 358,415 y 486 .

Ver también CoRTe IDH. 27 de junio de 2012 (sentencia). "Kichwa de Sarayaku”, párrafos 231,284 y 341.

134 Ver Corte IDH. 14 de octubre de 2014 (sentencia). “Kuna y Emberá”, párrafo 209. Ver también ibid., párrafos 210-3. 
sentencia en Segundo Norín Catrimán y otros (Dirigentes, miembros y activistas del pueblo indigena Mapuche) (2014) algunas de las obligaciones estatales que establece el artículo 21 , de acuerdo a su jurisprudencia sobre propiedad colectiva o comunal ${ }^{135}$. A diferencia de estos casos, en Kuna y Emberá el tribunal sí condenó al Estado demandado por incumplir dicha disposición convencional ${ }^{136}$. La responsabilidad internacional de Panamá se produjo por la demora o falta de demarcación, delimitación y titulación de las tierras de la propiedad colectiva de las comunidades indígenas Kuna y Emberá137. A este respecto, la responsabilidad internacional de Panamá no solo se derivó del incumplimiento del artículo 21. Según el tribunal, el estado demandado violó además los artículos 8.1 y 25 de la Convención Americana ${ }^{138}$. Al igual que en oportunidades anteriores, la Corte repitió varios de los criterios provenientes de Awas Tingni, Moiwana, Yakye Axa, Sawhoyamaxa, Xákmok Kásek y Kichwa de Sarayaku, y utilizó disposiciones de derecho comparado de estados miembros de la OEA y de otros tratados e instrumentos jurídicos internacionales, como el Convenio No 169 de la OIT y la Declaración de la ONU sobre los Derechos de los Pueblos Indígenas, para fundamentar sus razonamientos ${ }^{139}$. Probablemente el aspecto más destacable de Kuna y Emberá radica en la solución dada por el tribunal al conflicto que se presentó entre la propiedad colectiva de una de las comunidades Emberá y la propiedad individual de un particular, resuelto en este caso a favor de la primera por sobre el segundo, debido a la particular importancia que tiene la propiedad comunal para la supervivencia de todo pueblo indígena y $\operatorname{tribal}^{140}$. En su voto parcialmente disidente en Kuna y Emberá, el juez Eduardo Ferrer realizó una breve exposición de la jurisprudencia de la Corte sobre propiedad colectiva indígena y tribal ${ }^{141}$. Esto, a fin de analizar si el no pago de indemnizaciones constituye una violación continuada del artículo $21^{142}$. Su

135 Ver Corte Interamericana de Derechos Humanos. 30 de enero de 2014. Serie C No. 276 (voto concurrente del juez Ferrer Mac-Gregor). "Liakat Ali Alibux c. Surinam”, párrafo 79; y Corte IDH. 29 de mayo de 2014 (sentencia). "Norín Catrimán”, párrafo 155.

136 Respecto a este caso ver en general Sarmiento, Andrés (2015). "Case of Indigenous Communities Kuna of Madungandí and Emberá of Bayano and its Members v. Panama”. International Law - Revista Colombiana de Derecho Internacional, Vol. 27, pp. 9-38. Ver Corte IDH. 14 de octubre de 2014 (sentencia). "Kuna y Emberá", párrafos 137, 146 y 157. Ver también ibid., párrafos 1, 124-46 y 150-60.

138 Ver Corte IDH. 14 de octubre de 2014 (sentencia). "Kuna y Emberá”, párrafos 173 y 187. Ver también ibid., párrafos 170-87 y 192-8.

139 Ver Corte IDH. 14 de octubre de 2014 (sentencia). "Kuna y Emberá”, párrafos 111-23 y 142.

140 Ver Corte IDH. 14 de octubre de 2014 (sentencia). "Kuna y Emberá”, párrafos 138-45.

141 Ver Corte IDH. 14 de octubre de 2014. (voto parcialmente disidente del juez Ferrer MacGregor). "Kuna y Emberá”, párrafos 6-30.

142 Ver Corte IDH. 14 de octubre de 2014. (voto parcialmente disidente del juez Ferrer MacGregor). "Kuna y Emberá", párrafos 31-59. 
conclusión fue que sí, y que la Corte debiera haber examinado y fallado este punto en su sentencia ${ }^{143}$. Según el juez Ferrer:

[...] es pertinente advertir que sería una falacia y un argumento de reducción al absurdo (reductio ad absurdum) pretender que cualquier tipo de expropiación de tierras indígenas presente, futura, pero sobre todo del pasado, constituye por ese solo hecho una situación continuada. Realizar dicha afirmación crearía una absoluta falta de certeza jurídica respecto a cualquier propiedad en el continente americano. Sin embargo, adoptar tajantemente la posición opuesta en lo general, sin analizar las circunstancias particulares de cada caso resulta desproporcional como sucedió en el presente caso en el que se está ante una situación continuada por un hecho compuesto relativo al incumplimiento del pago de la indemnización-, dejando en desventaja a grupos de personas y comunidades que esta misma Corte ha reconocido como poseedores de una protección particular por parte del derecho internacional de los derechos humanos ${ }^{144}$.

Casi un año más tarde, la Corte nuevamente resumió su jurisprudencia sobre propiedad comunal en dos casos presentados por la Comisión Interamericana en contra de Honduras, por haber violado el artículo 21 en detrimento de comunidades indígenas. Garifuna de Punta Piedra y Garifuna Triunfo de la Cruz fueron fallados el mismo día. En ambas sentencias, el tribunal no solo se refirió al canon compuesto por las sentencias que van desde Awas Tingni a Kichwa de Sarayaku, sino que incorporó a este listado a Kuna y Emberá ${ }^{145}$. Para interpretar y aplicar el artículo 21, el tribunal una vez más se apoyó en el Convenio No 169, la Declaración sobre los Derechos de los Pueblos Indígenas y otros instrumentos jurídicos internacionales no vinculantes, que en Garifuna de Punta Piedra incluyó a la Declaración Americana de Derechos y Deberes del Hombre de 1948, así como en el derecho comparado, concretamente de estados miembros de la OEA ${ }^{146}$. Como en otras

143 Ver Conte IDH. 14 de octubre de 2014. (voto parcialmente disidente del juez Ferrer MacGregor). "Kuna y Emberá", párrafos 60-78.

144 Corte IDH. 14 de octubre de 2014. (voto parcialmente disidente del juez Ferrer MacGregor). "Kuna y Emberá", párrafo 78.

145 Ver Corte IDH. 8 de octubre de 2015 (sentencia). "Garífuna de Punta Piedra”, párrafos 165-7, 169, 215-6 y 222-3; y CorTe IDH. 8 de octubre de 2015 (sentencia). "Garífuna Triunfo de la Cruz", párrafos 100-7, 121, 142, 154-6, 158-60, 162-3 y 179-80.

Ver tambien Corte IDH. 8 de octubre de 2015 (sentencia). "Garífuna de Punta Piedra”, párrafos 231-3; y ConTe IDH. 8 de octubre de 2015 (sentencia). "Garífuna Triunfo de la Cruz", párrafos 227-8.

146 Ver Corte IDH. 8 de octubre de 2015 (sentencia). "Garífuna de Punta Piedra”, párrafos 84-5, 91, 168, 173-6, 178-9, 217, 220 y 223; y CoRTE IDH. 8 de octubre de 2015 (sentencia). "Garífuna Triunfo de la Cruz", párrafos 48-9, 57, 103, 107, 119, 122, 126, 135-6, $138,150,158,161,171,179,190$ y 196. 
de sus sentencias condenatorias por violación al artículo 21, el tribunal concluyó que Honduras había incumplido también el artículo 25 del Pacto de San José de Costa Rica, en Garifuna de Punta Piedra, y los artículos 2, 8.1 y 25 de este tratado, en Garifuna Triunfo de la Cruz ${ }^{147}$. Tanto en un caso como en el otro, la Corte consideró como parte lesionada a la comunidad garífuna respectiva y a sus miembros, quienes en su carácter de víctimas fueron los beneficiarios de las reparaciones ordenadas ${ }^{148}$. A pesar de esta declaración, el tribunal estableció en las dos sentencias reparaciones de carácter colectivo a favor de las comunidades indígenas ${ }^{149}$.

En Garifuna de Punta Piedra, la Comisión Interamericana alegó que Honduras violó el artículo 21 al haber otorgado títulos de dominio a favor de la comunidad indígena correspondiente sin haberlos saneado adecuadamente, dejando a sus ocupantes jurídicamente desprotegidos frente a ter$\operatorname{ceros}^{150}$. La Corte declaró en su sentencia que el saneamiento "consiste en un proceso que deriva en la obligación del Estado de remover cualquier tipo de interferencia sobre el territorio en cuestión"151. Para el tribunal, la falta de saneamiento del territorio de la comunidad garífuna de Punta Piedra llevó a la presencia de terceros en sus tierras, constituyendo una violación del artículo 21 que le ha impedido usar y gozar del derecho de propiedad colectiva, tal como lo reconoce y protege esta disposición de la Convención Americana ${ }^{152}$. La Corte volvió a referirse en Garífuna de Punta Piedra a los derechos de consulta e identidad cultural, como ya lo hiciera en Saramaka y Kichwa de Sarayaku ${ }^{153}$. En relación a la obligación de consulta, la sentencia

147 Ver Conte IDH. 8 de octubre de 2015 (sentencia). "Garífuna de Punta Piedra”, párrafos 234-51 y 372; y Corte IDH. 8 de octubre de 2015 (sentencia). "Garífuna Triunfo de la Cruz", párrafos 188, 196-200 y 231-51.

148 Ver Corte IDH. 8 de octubre de 2015 (sentencia). “Garífuna de Punta Piedra”, párrafo 317; y Corte IDH. 8 de octubre de 2015 (sentencia). "Garífuna Triunfo de la Cruz", párrafo 257.

149 Ver Corte IDH. 8 de octubre de 2015 (sentencia). "Garífuna de Punta Piedra", párrafos 322-8, 332-6 y 372; y CoRTe IDH. 8 de octubre de 2015 (sentencia). "Garífuna Triunfo de la Cruz", párrafos 259-64, 268-9 y 289-99.

150 Corte IDH. 8 de octubre de 2015 (sentencia). "Garífuna de Punta Piedra”, párrafo 159. Ver ibid., párrafos 1 y 170.

En este caso, el Estado hondureño hizo un reconocimiento parcial de su responsabilidad. Ver Conte IDH. 8 de octubre de 2015 (sentencia). "Garífuna de Punta Piedra”, párrafos 45 y 162.

151 Corte IDH. 8 de octubre de 2015 (sentencia). "Garífuna de Punta Piedra”, párrafo 181. El tribunal agregó a continuación: "En particular, [el saneamiento] se realizará a través de la posesión plena del legítimo propietario y, de ser procedente y según lo acordado, mediante el pago de mejoras y la reubicación de los terceros ocupantes [...]".

Corte IDH. 8 de octubre de 2015 (sentencia). "Garífuna de Punta Piedra", párrafo 181.

152 Ver Corte IDH. 8 de octubre de 2015 (sentencia). "Garífuna de Punta Piedra”, párrafos 182-202.

153 Ver Conte IDH. 8 de octubre de 2015 (sentencia). “Garífuna de Punta Piedra”, párrafos 215-8 y 222-3. 
insistió en que debe realizarse "con carácter previo, de buena fe, con la finalidad de llegar a un acuerdo", para lo cual requiere ser "adecuada, accesible e informada" 154 . Conforme al tribunal, Honduras no efectuó un proceso consulta que cumpla con estas características. Esta falta de consulta, sumada al hecho que las disposiciones reglamentarias que complementan la legislación hondureña sobre el tema carecen de la precisión necesaria sobre el carácter previo de la consulta, constituyeron una violación del artículo $21^{155}$.

El segundo caso que se falló en contra de Honduras el 8 de octubre de 2015 es Garifuna Triunfo de la Cruz. En esta sentencia, la Corte condenó a dicho estado por incumplir el artículo 21 al haber cometido algunos de los hechos alegados por la Comisión Interamericana durante el proceso ${ }^{156}$. En concreto, por no haber delimitado y demarcado parte del territorio de la comunidad indígena, por no haber titulado otra porción de este, y por haber delimitado y titulado en un plazo no razonable otra porción más; por no haber protegido el territorio de los garífuna Triunfo de la Cruz frente a terceros ocupantes de parte de este; por no haber efectuado consultas para los proyectos turísticos y el área protegida ubicada en su territorio; y por no haber realizado un estudio de impacto ambiental y social para dichos proyectos turísticos ${ }^{157}$. Si bien la Corte no se pronunció sobre la alegada violación del artículo 21 por la falta de delimitación, demarcación y titulación de partes de la playa y del mar adyacente al territorio de la comunidad garífuna, recordó obiter dictum el deber de los estados de "garantizar el uso, goce y utilización en igualdad de condiciones y sin discriminación a las playas y mares costeros y otros recursos que tradicionalmente han utilizado, de conformidad con sus usos y costumbres" ${ }^{158}$. A esta sentencia, el juez Humberto Sierra adjuntó un voto concurrente, en el que destacó la reparación colectiva ordenada por la Corte en Garífuna Triunfo de la Cruz, particularmente la creación de un fondo de desarrollo comunitario, e hizo un recuento de la jurisprudencia del tribunal sobre el reconocimiento de la personalidad jurí-

Al igual que en Kuna y Emberá, la identidad cultural de los pueblos indígenas y tribales solo fue mencionada al pasar en Garifuna de Punta Piedra.

Ver Corte IDH. 14 de octubre de 2014 (sentencia). "Kuna y Emberá”, párrafo 112.

154 Corte IDH. 8 de octubre de 2015 (sentencia). "Garífuna de Punta Piedra”, párrafo 216.

155 Ver Corte IDH. 8 de octubre de 2015 (sentencia). "Garífuna de Punta Piedra”, párrafos $220-4$.

156 Ver Corte IDH. 8 de octubre de 2015 (sentencia). “Garífuna Triunfo de la Cruz”, párrafos 1 y $91-3$.

157 Ver Conte IDH. 8 de octubre de 2015 (sentencia). “Garífuna Triunfo de la Cruz”, párrafos 119-29, 138-73, 177-82.

Ver ibid., parrafos 116-8.

158 Corte IDH. 8 de octubre de 2015 (sentencia). "Garífuna Triunfo de la Cruz”, párrafo 137. Ver ibid., párrafos 131-7. 
dica de los pueblos indígenas y tribales y el daño colectivo que pueden sufrir estos por parte de los estados donde se ubican sus tierras y territorios ${ }^{159}$.

El más reciente de los casos fallados en contra de un Estado demandado por incumplir el artículo 21, es Kaliña y Lokono. Como ya es habitual en este tipo de sentencias, la Corte expuso detalladamente su jurisprudencia sobre el tema, antes de aplicar a Surinam las obligaciones internacionales que la Convención Americana establece, esta vez en relación a un pueblo indígena, y no tribal como en Moiwana y Saramaka. A su listado de sentencias citadas, Kaliña y Lokono agregó a Garífuna de Punta Piedra y Garifuna Triunfo de la Cruz, y confirmó la importancia de Kuna y Emberá⿴囗十 ${ }^{160}$. El tribunal comenzó su análisis del artículo 21 del Pacto de San José de Costa Rica reiterando las razones dadas en Saramaka para considerar que el Convenio $\mathrm{N}^{\circ} 169$ de la OIT es aplicable a Surinam, no obstante que no es parte de este tratado ${ }^{161}$. La Corte condenó a este Estado por no haber delimitado, demarcado y titulado los territorios colectivos; por haber otorgado títulos de propiedad y otros a terceros en las tierras reclamadas por los Kaliña y Lokono; por haber afectado la propiedad de estas comunidades indígenas, impidiendo la participación y acceso a parte de sus tierras y recursos naturales en un par de reservas establecidas por Surinam en sus territorios para proteger el medio ambiente; por no haber establecido e implementado un proceso de consulta con anterioridad al otorgamiento de concesiones mineras en dicho territorio; y por no haber realizado un estudio de impacto ambiental y social previo a la explotación de los yacimientos correspondientes, ni haber compartido razonablemente los beneficios de los proyectos en cuestión con los Kalina y Lokono ${ }^{162}$. De acuerdo al tribunal, el estado demandado no solo incumplió el derecho de propiedad colectiva, sino también el derecho de identidad cultural y el derecho de protección judicial de tales pueblos indígenas, consagrados respectivamente en los artículos 21 y 25 de la Convención Americana, debidamente concordados con

159 Ver Corte IDH. 8 de octubre de 2015 (voto concurrente del juez Sierra Porto). "Garífuna Triunfo de la Cruz", párrafos 20-63.

Sorprende, que en su recuento el juez Humberto Sierra no mencione el voto concurrente del juez Eduardo Vio en Xákmok Kásek.

160 Ver Corte IDH. 25 de noviembre de 2015 (sentencia). "Kaliña y Lokono", párrafos 122-5, 129-34, 138-9, 141, 149-51, 155-8, 164-5, 200-1, 206, 214-5 y 227.

Ver ibid., párrafos 237-8, 240, 242-4, 248 y 251.

161 Ver CoRTe IDH. 25 de noviembre de 2015 (sentencia). "Kalińa y Lokono", párrafos 122-5. Ver también CoRTe IDH. 28 de noviembre de 2007 (sentencia). "Saramaka", párrafos 93-6.

162 Ver Corte IDH. 25 de noviembre de 2015 (sentencia). "Kaliña y Lokono", párrafos 13442, 144-60, 166-8, 190-8, 200, 206-12, 216-26 у 228-30. 
otros preceptos del mismo tratado y disposiciones extra interamericanas ${ }^{163}$. En Kaliña y Lokono, el tribunal de nuevo fundamentó su argumentación en otros tratados, dentro de los cuales ocupó un lugar destacado el Convenio No 169, y en instrumentos jurídicos internacionales no vinculantes, que en esta ocasión incluyeron a los Principios Rectores de la ONU sobre las Empresas y los Derechos Humanos del 2011, además de la Declaración sobre los Derechos de los Pueblos Indígenas, y otros ${ }^{164}$. El rasgo más sobresaliente de esta sentencia, desde el punto de vista del desarrollo de la jurisprudencia sobre propiedad comunal de la Corte, se refiere a la compatibilidad entre la protección ambiental y los derechos de los pueblos indígenas y tribales ${ }^{165}$. En este punto, el tribunal señaló que:

[...] un área protegida, consiste no solamente en la dimensión biológica, sino también en la sociocultural y que, por tanto, incorpora un enfoque interdisciplinario y participativo. En este sentido, los pueblos indígenas, por lo general, pueden desempeñar un rol relevante en la conservación de la naturaleza, dado que ciertos usos tradicionales conllevan prácticas de sustentabilidad y se consideran fundamentales para la eficacia de las estrategias de conservación. Por ello, el respeto de los derechos de los pueblos indígenas, puede redundar positivamente en la conservación del medio ambiente. Así, el derecho de los pueblos indígenas y las normas internacionales de medio ambiente deben comprenderse como derechos complementarios y no excluyentes ${ }^{166}$.

Siguiendo un criterio que se ha mantenido inalterable desde Kuna y Emberá, la Corte consideró como parte lesionada en Kaliña y Lokono a los pueblos indígenas y sus miembros, ordenando reparaciones colectivas a favor de dichas comunidades ${ }^{167}$. Los jueces Humberto Sierra y Eduardo Ferrer acompańaron un voto concurrente donde se refirieron a las obligaciones de consulta y de reconocimiento de la personalidad jurídica colec-

163 Ver CoRTe IDH. 25 de noviembre de 2015 (sentencia). "Kalińa y Lokono", párrafos 197-8, 244-60 y 263-8.

164 Ver Corte IDH. 25 de noviembre de 2015 (sentencia). "Kaliña y Lokono", párrafos 122-4, 128, 139, 172-81, 196, 202, 214, 221, 224-5, 246 у 248.

Los Principios Rectores sobre las Empresas y los Derechos Humanos fueron aprobados por el Consejo de Derechos Humanos de la ONU el 2011. Están disponibles en: http:// www.ohchr.org/Documents/Publications/GuidingPrinciplesBusinessHR_SP.pdf [visitado el $15 / 3 / 2015]$.

165 Ver Corte IDH. 25 de noviembre de 2015 (sentencia). "Kalińa y Lokono”, párrafos 171-

166 Corte IDH. 25 de noviembre de 2015 (sentencia). "Kalińa y Lokono”, párrafo 173. Ver ibid., párrafos 181 y 191-2.

167 Ver Corte IDH. 25 de noviembre de 2015 (sentencia). "Kaliña y Lokono”, párrafos 273, 279-87, 290-1, 295-9, 304-5 у 329. 
tiva ${ }^{168}$. En cuanto a la consulta, los jueces Sierra y Ferrer recordaron que la Corte se había pronunciado sobre esta en cuatro sentencias anteriores: Saramaka, Kichwa de Sarayaku, Garifuna de Punta Piedra y Garifuna Triunfo de la $\mathrm{Cruz}^{169}$. Asimismo, resaltaron que la obligación de consulta debe cumplirse en forma previa a las distintas etapas que componen un proyecto de exploración y explotación de recursos naturales. En otras palabras, que su cumplimiento no debe limitarse únicamente a las primeras etapas de la concesión respectiva ${ }^{170}$.

\section{CONCLUSIÓN}

La propiedad colectiva es un derecho establecido jurisprudencialmente en el sistema interamericano. Como los derechos colectivos de consulta y a la identidad cultural de los pueblos indígenas y tribales, la propiedad comunal ha sido reconocida y desarrollada por la Corte a través de una interpretación evolutiva y pro homine del artículo 21 del Pacto de San José de Costa Rica, donde la coordinación con otros tratados e instrumentos jurídicos tiene un rol esencial. Para este fin, el tribunal también ha recurrido a la jurisprudencia internacional extra interamericana $y$ al derecho comparado para fundamentar criterios que va reconociendo y confirmando, sentencia tras sentencia. A la fecha, el tribunal ha condenado en trece oportunidades a estados demandados por incumplir el artículo 21, sea en perjuicio de los miembros de un pueblo indígena o tribal, o del pueblo mismo. Cuando la Corte pronunció su decisión judicial en Awas Tingni, el Convenio No 169 de la OIT ya estaba vigente. Si bien el influjo de sus disposiciones es evidente en la interpretación dada en esta sentencia al artículo 21 de la Convención Americana, el tribunal se cuidó de no citarla expresamente en sus consideraciones, probablemente debido a que Nicaragua no era entonces parte del tratado de la OIT. Lo mismo pasó en Moiwana respecto de Surinam, que no ha ratificado el Convenio No 169. A partir de Yakye Axa, la Corte ha utilizado de manera explícita el tratado de la OIT para interpretar lo dispuesto en el artículo 21 del Pacto de San José de Costa Rica. Lo hizo así en los casos entablados en contra de Paraguay y Ecuador, que ya eran parte del tratado de la OIT al momento del fallo con-

\footnotetext{
168 Ver en general Corte Interamericana de Derechos Humanos. 25 de noviembre de 2015. Serie C No. 309 (voto concurrente conjunto de los jueces Sierra Porto y Ferrer MacGregor). "Pueblos Kaliña y Lokono c. Surinam".

169 Ver Corte IDH. 25 de noviembre de 2015 (voto concurrente conjunto de los jueces Sierra Porto y Ferrer Mac-Gregor). "Kalińa y Lokono", párrafo 5. Ver ibid., párrafos 4-8.

170 Ver Corte IDH. 25 de noviembre de 2015 (voto concurrente conjunto de los jueces Sierra Porto y Ferrer Mac-Gregor). "Kaliña y Lokono”, párrafos 13-6.
} 
denatorio respectivo de la Corte, y no se apartó de esta línea en Saramaka ni en Kaliña y Lokono, aun cuando Surinam todavía no es parte del Convenio No 169.

Fue precisamente en Saramaka que la Corte comenzó a mencionar la Declaración de la ONU sobre los Derechos de los Pueblos Indígenas, un par de meses después que la Asamblea General de la ONU la aprobara. Este fue el primer instrumento jurídico no vinculante que la Corte Interamericana empleó al interpretar y aplicar la protección convencional de la propiedad colectiva indígena y tribal. Sin embargo, no ha sido el único. Las sentencias del tribunal han hecho referencia, por ejemplo, a la Declaración de Río sobre el Medio Ambiente y el Desarrollo, los Principios Rectores sobre las Empresas y los Derechos Humanos, los informes de los relatores especiales de la ONU sobre la situación de los derechos humanos y las libertades fundamentales de los pueblos indígenas, y los informes de órganos de tratados, sean estos establecidos en virtud del Convenio No 169 de la OIT u otros acuerdos internacionales. Desde sus inicios en Awas Tingni, la jurisprudencia interamericana sobre propiedad comunal indígena y tribal además se ha nutrido del derecho comparado. No obstante, solo a partir de Kichwa de Sarayaku la Corte ha ofrecido un estudio que merezca ser calificado de propiamente comparativo. Kuna y Emberá, Garifuna de Punta Piedra, Garifuna Triunfo de la Cruz y Kaliña y Lokono reiteran esta perspectiva comparativa, centrada principalmente en el derecho de los estados miembros de la OEA. Las menciones a la jurisprudencia de los sistemas africano y europeo sobre pueblos indígenas y otras minorías son todavía marginales, pero todo indica que la Corte recurrirá en el futuro a estas para fundamentar unos criterios interpretativos que requerirán necesariamente de apoyo externo para seguir consolidándose.

\section{Bibliografía CITADA}

Aguilar, Gonzalo (ed.) (2014): Diálogo entre jurisdicciones: el desarrollo del derecho público y una nueva forma de razonar. Santiago: Librotecnia, 493 pp.

Aguilar, Gonzalo (2007): Dinámica internacional de la cuestión indígena. Santiago: Librotecnia, 658 pp.

Alvarado, Leonardo (2007). "Prospects and Challenges in the Implementation of Indigenous Peoples' Human Rights in International Law: Lessons from the Case of Awas Tingni $v$. Nicaragua". Arizona Journal of International and Comparative Law, Vol. 24, pp. 609-43.

Anaya, James (2004): Indigenous Peoples in International Law. Nueva York: Oxford University Press, 396 pp. 
Anaya, James (2005). “Indigenous Peoples' Participatory Rights in Relation to Decisions about Natural Resource Extraction: The More Fundamental Issue of What Rights Indigenous Peoples Have in Lands and Resources". Arizona Journal of International and Comparative Law, Vol. 22, pp. 7-17.

Anaya, James, y Grossman, Claudio (2002). "The Case of Awas Tingni v. Nicaragua: A Step in the International Law of Indigenous Peoples". Arizona Journal of International and Comparative Law, Vol. 19, pp. $1-15$.

Anaya, James, y Williams, Robert (2001). “The Protection of Indigenous Peoples' Rights over Lands and Natural Resources under the InterAmerican Human Rights System”. Harvard Human Rights Journal, Vol. 14, pp. 33-86.

Antkowiak, Thomas (2007). "Moiwana Village v. Suriname: A Portal into Recent Jurisprudential Developments of the Inter-American Court of Human Rights". Berkeley Journal of International Law, Vol. 25, pp. 268-82.

BArelli, Mauro (2009). "The Role of Soft Law in the International Legal System: the Case of the United Nations Declaration on the Rights of Indigenous Peoples”. International \& Comparative Law Quarterly, Vol. 58, pp. 957-8.

Bengoa, José (2007): La emergencia indigena en América Latina. Santiago: Fondo de Cultura Económica, 343 pp.

BJorge, Eirik (2014): The Evolutionary Interpretation of Treaties. Oxford: Oxford University Press, $240 \mathrm{pp}$.

Brunner, Lisl (2008). “The Rise of Peoples' Rights in the Americas: The Saramaka People Decision of the Inter-American Court of Human Rights". Chinese Journal of International Law, Vol. 7 No 3, pp. 699711.

Burgorgue-Larsen, Laurence (2013): El diálogo judicial. Máximo desafío de los tiempos juridicos modernos. México, D.F.: Editorial Porrúa, 315 pp.

Comisión Interamericana de Derechos Humanos (2010): Derechos de los pueblos indigenas y tribales sobre sus tierras ancestrales y recursos naturales: normas y jurisprudencia del sistema interamericano de derechos humanos. Washington D.C.: OEA documentos oficiales, 148 pp.

Commission, Jeffery (2007). "Precedent in Investment Treaty Arbitration. A Citation Analysis of a Developing Jurisprudence”. Journal of International Arbitration, Vol. $24 \mathrm{~N}^{\circ}$ 2, pp. 129-58.

Dannenmaier, Eric (2008). "Beyond Indigenous Property Rights: Exploring the Emergence of a Distinctive Connection Doctrine". Washington University Law Review, Vol. 86, pp. 53-110. 
Del Toro, Mauricio (2010). "El derecho de propiedad colectiva de los miembros de comunidades y pueblos indígenas en la jurisprudencia de la Corte Interamericana de Derechos Humanos". Anuario Mexicano de Derecho Internacional, Vol. 10, pp. 49-95.

Dhommeaux, Jean (2009): "Les communautés autochtones et tribales dans la jurisprudence de la Cour Interaméricaine des Droits de l'Homme". En Hennebel, Ludovic, y Tigroudja, Hélène (eds.): Le particularisme interaméricain des droits de l'homme: en l'honneur du 40e anniversaire de la Convention Américaine des Droits de l'Homme. París: Editions A. Pedone, pp. 181-213.

Dolzer, Rudolf, y Schreuer, Christoph (2012): Principles of International Investment Law. Oxford: Oxford University Press, 456 pp.

ECLAC (2005): The Millennium Development Goals: A Latin American and Caribbean Perspective. Santiago: Publicaciones de la ONU, 321 pp.

Eide, Asbjorn (2006). "Rights of Indigenous Peoples - Achievements in International Law during the Last Quarter of a Century”. Netherlands Yearbook of International Law, Vol. 37, pp. 155-212.

Fernández, Alejandro, y De la Piedra, Christian (2011). "Implementación y evolución de los derechos contenidos en el Convenio OIT 169: aporte de la jurisprudencia y pronóstico de desarrollo futuro de sus implicancias ambientales y regulatorias". Estudios Públicos, Vol. 121, pp. 71-132.

Ferrer, Eduardo, y Herrera, Alfonso (eds.) (2013): Diálogo jurisprudencial en derechos humanos: entre tribunales constitucionales $y$ cortes internacionales. Valencia: Editorial Tirant lo Blanch, $1412 \mathrm{pp}$.

Forero, Felipe (2010). "Conectividad: alcances del derecho a la propiedad aborigen y tribal en la jurisprudencia de la Corte Interamericana de Derechos Humanos". International Law - Revista Colombiana de Derecho Internacional, Vol. 16, pp. 177-211.

Fuentes, Carlos Iván (2005). "Universalidad y diversidad cultural en la interpretación de la Convención Americana sobre Derechos Humanos: Innovaciones en el caso de la Comunidad Indígena Yakye Axa”. Revista CEJIL, Vol. 1 No 2, pp. 69-77.

Gaete, Lucía (2012). "El Convenio N 169. Un análisis de sus categorías problemáticas a la luz de su historia normativa". Ius et Praxis, Vol. 18 $\mathrm{N}^{\circ}$ 2, pp. 77-124.

Gardiner, Richard (2010): Treaty Interpretation. Oxford: Oxford University Press, 409 pp.

Gómez del Prado, José Luis (2002): Pueblos indigenas. Normas internacionales y marcos nacionales. Bilbao: Publicaciones de la Universidad de Deusto, 122 pp. 
Gómez, Magdalena (2006): "El Convenio 169 de la Organización Internacional del Trabajo". En Berraondo, Mikel (ed.): Pueblos indigenas y derechos humanos. Bilbao: Publicaciones de la Universidad de Deusto, pp. 133-51.

Gómez Isa, Felipe (ed.) (2013): El caso Awas Tingni. Derechos humanos entre lo local y lo global. Bilbao: Publicaciones de la Universidad de Deusto, $251 \mathrm{pp}$.

GonzA, Alejandra (2014): "Artículo 21. Derecho a la propiedad privada". En Steiner, Christian, y Uribe, Patricia (eds.): Convención Americana sobre Derechos Humanos: comentario. La Paz: Fundación Konrad Adenauer, pp. 503-30.

Hannum, Hurst (2003): "Indigenous Rights". En Lyons, Gene, y MaYall, James (eds): International Human Rights in the 21st Century: Protecting the Rights of Groups, pp. 72-99.

Harris, David, et al. (2009): Law of the European Convention on Human Rights. Oxford: Oxford University Press, 960 pp.

Henriksen, John (2008): Key Principles in Implementing ILO Convention No. 169. Ginebra: Publicaciones de la OIT, 83 pp.

Hervé, Dominique, y Pérez, Sergio (2012): “Adecuación de la legislación interna a los estándares impuestos para la administración de recursos naturales". En Contesse, Jorge (ed.): El Convenio 169 de la OIT y el derecho chileno. Mecanismos y obstáculos para su implementación. Santiago: Ediciones Universidad Diego Portales, pp. 15-101.

JАСОВ, Marc (2011). "Precedents: Lawmaking through International Adjudication". German Law Journal, Vol. 12 N 5, pp. 1005-32.

Kingsbury, Benedict (1998). "Indigenous Peoples' in International Law: A Constructivist Approach to the Asian Controversy'. American Journal of International Law; Vol. $92 \mathrm{~N}^{\circ}$ 2, pp. 414-57.

LinderfalK, Ulf (2015). "Cross-Fertilisation in International Law". Nordic Journal of International Law, Vol. $84 \mathrm{~N}^{\circ} 3$, pp. 428-55.

Linderfalk, Ulf (2007): On the Interpretation of Treaties: The Modern International Law as Expressed in the 1969 Vienna Convention on the Law of Treaties. Dordrecht: Springer, $440 \mathrm{pp}$.

López Escarcena, Sebastián (2014): Indirect Expropriation in International Law. Cheltenham: Edward Elgar Publishing, 254 pp.

López Escarcena, Sebastián (2012). "Interferences with Property under European Human Rights Law". Florida Journal of International Law, Vol. $24 \mathrm{~N}^{\circ} 3$, pp. 513-44.

López Escarcena, Sebastián (2015). "La propiedad y su privación o restricción en la jurisprudencia de la Corte Interamericana". Ius et Praxis, Vol. $21 \mathrm{~N}^{\circ}$ 1, pp. 531-76. 
López Escarcena, Sebastián (2016). “Operación Génesis: reflexiones en torno a la propiedad indígena y tribal”. Estudios Socio-Juridicos, Vol. 18 No 1, pp. 136-68

López-Murcia, Julián, y Maldonado, Gabriela (2009). "La Protección de la Propiedad de la Tierra en la Jurisprudencia de la Corte Interamericana de Derechos Humanos y su Aplicación al Caso de las Comunidades Campesinas en Colombia”. International Law: Revista Colombiana de Derecho Internacional, Vol. 14, pp.71-105.

Marcelli, Fabio (2011): Los derechos de los pueblos indigenas. Medellín: Librería Jurídica Sánchez, 177 pp.

Martin, Claudia (2006). "The Moiwana Village Case: A New Trend in Approaching the Rights of Ethnic Groups in the Inter-American System". Leiden Journal of International Law, Vol. 19, No 2, pp. 491504.

Mazzuoli, Valerio de Oliveira, y Ribeiro, Dilton (2016). "The Pro Homine Principle as an Enshrined Feature of International Human Rights Law”. Indonesian Journal of International \& Comparative Law, Vol. $3 \mathrm{~N}^{\circ}$ 1, pp. 77-99.

Mereminskaya, Elina (2011). "El Convenio 169 de la OIT sobre pueblos indígenas y tribales: derecho internacional y experiencias comparadas". Estudios Públicos, Vol. 121, pp. 213-76.

Meza-Lopehandía, Matías (2014): "El Convenio No 169 sobre pueblos indígenas y tribales de la Organización Internacional del Trabajo”. En Aylwin, José (ed.): Los pueblos indigenas y el derecho. Santiago: Lom Ediciones, pp. 337-439.

Montt, Santiago, y Matta, Manuel (2011). "Una visión panorámica al Convenio OIT 169 y su implementación en Chile". Estudios Públicos, Vol. 121, pp. 133-212.

Nash, Claudio (2013): "El principio pro persona en la jurisprudencia de la Corte Interamericana de Derechos Humanos". En Nogueira, Humberto (ed.) (2013): Diálogo judicial multinivel y principios interpretativos favor persona y de proporcionalidad. Santiago: Librotecnia, pp. 155-99.

Nash, Claudio (2008). "Los derechos indígenas en el sistema interamericano de derechos humanos". 1/I Inter-American and European Human Rights Journal, Vol. $1 \mathrm{~N}^{\circ}$ 1, pp. 61-86

Newcombe, Andrew, y Paradell, Lluís (2009): Law and Practice of Investment Treaties: Standards of Treatment. Alphen aan den Rijn: Kluwer Law International, 614 pp.

Nikken, Pedro (2009): "Balancing of Human Rights and Investment Law in the Inter-American System of Human Rights". En Dupuy, Pierre-Marie, Francioni, Francesco, y Petersmann, ErnstUlrich (eds.): Human Rights in International Investment Law and Arbitration. Oxford: Oxford University Press, pp. 246-71. 
Nogueira, Humberto (ed.) (2013): Diálogo judicial multinivel y principios interpretativos favor persona y de proporcionalidad. Santiago: Librotecnia, 339 pp.

Nogueira, Humberto (ed.) (2012): El diálogo transjudicial de los tribunales constitucionales entre si y con las cortes internacionales de derechos humanos. Santiago: Librotecnia, 525 pp.

Nogueira, Humberto (ed.) (2014): La protección de los derechos humanos y fundamentales de acuerdo a la Constitución y el derecho internacional de los derechos humanos. Santiago: Librotecnia, $492 \mathrm{pp}$.

Olivares, Efrén (2013). "Indigenous Peoples' Rights and the Extractive Industry: Jurisprudence from the Inter-American System of Human Rights". Goettingen Journal of International Law, Vol. $5 \mathrm{~N}^{\circ}$ 1, pp. 187-214.

Orellana, Marcos (2008). "Saramaka People v. Suriname". American Journal of International Law, Vol. 102 No 4, pp. 841-7.

Organización Internacional del Trabajo (2009): Los derechos de los pueblos indigenas y tribales en la práctica - Una guia sobre el Convenio $N^{\circ} 169$ de la OIT. Ginebra: Publicaciones de la OIT, $200 \mathrm{pp}$.

Ormachea, Pablo (2006). "Moiwana Village: The Inter-American Court and the Continuing Violation Doctrine Recent Developments". Harvard Human Rights Journal, Vol. 19, pp. 283-8.

OsтвY, Anne (2003). "Will Foreign Investors Regulate Indigenous Peoples' Right to Self-Determination". Wisconsin International Law Journal, Vol. 21 No 1, pp. 223-50.

Pasqualucci, Jo (2009). "International Indigenous Land Rights: A Critique of the Jurisprudence of the Inter-American Court of Human Rights in Light of the United Nations Declaration on the Rights of Indigenous Peoples". Wisconsin International Law Journal, Vol. $27 \mathrm{~N}^{\circ} 1$, pp. 51-98.

Patiño, Luz (2014). "Fundamentos y práctica internacional del derecho a la consulta previa, libre e informada a pueblos indígenas". Anuario Colombiano de Derecho Internacional, Vol. 7, pp. 69-111.

Paulsson, Jan (2010): "The Role of Precedent in Investment Arbitration”. En YannaCa-Small, Katia (ed.): Arbitration under International Investment Agreements: A Guide to the Key Issues. Nueva York: Oxford University Press, pp. 699-718.

Pentassuglia, Gaetano (2011). "Towards a Jurisprudential Articulation of Indigenous Land Rights". European Journal of International Law, Vol. $22 \mathrm{~N}^{\circ} 1$, pp. 165-202.

Ramírez, Andrés (2005). "El caso de la comunidad indígena Yakye Axa vs. Paraguay". Revista IIDH, Vol. 41, pp. 347-64.

Ramos, André de Carvalho (2014): Curso de direitos humanos. São Pablo: Editora Saraiva, 656 pp. 
Ramos, André de Carvalho (2014): Teoria geral dos direitos humanos na ordem internacional. São Pablo: Editora Saraiva, 343 pp.

Rinaldi, Karine (2009): "Le droit des populations autochtones et tribales à la propriété dans le système interaméricain de protection des droits de l'homme". En Hennebel, Ludovic, y Tigroudja, Hélène (eds.): Le particularisme interaméricain des droits de l'homme: en l'honneur du 40e anniversaire de la Convention Américaine des Droits de l'Homme. París: Editions A. Pedone, 2009, pp. 215-50.

Rivera Juaristi, Franciso, y Rinaldi, Karine (2008). "Pueblo Saramaka vs. Surinam: el derecho a la supervivencia de los pueblos indígenas y tribales como pueblos". Revista CEJIL, Vol. 3 No 4, pp. 80-96.

Rodríguez, Gabriela (2014): "Artículo 29. Normas de interpretación". En Steiner, Christian, y Uribe, Patricia (eds.): Convención Americana sobre Derechos Humanos: comentario. La Paz: Fundación Konrad Adenauer, pp. 706-14.

Rodríguez Garavito, César, y Morris, Megan (eds.) (2010): La consulta previa a pueblos indigenas: los estándares del derecho internacional. Bogotá: Ediciones Uniandes, 96 pp.

Rodríguez-Piñero, Luis (2013): "El impacto internacional de la sentencia”. En Gómez Isa, Felipe (ed.): El caso Awas Tingni. Derechos humanos entre lo local y lo global. Bilbao: Publicaciones de la Universidad de Deusto, pp. 163-203.

Rodríguez-PiÑero, Luis (2006): "El sistema interamericano de derechos humanos y los pueblos indígenas”. En Berraondo, Mikel (ed.): Pueblos indigenas y derechos humanos. Bilbao: Publicaciones de la Universidad de Deusto, pp. 153-203.

Rodríguez-Piñero, Luis (2005): Indigenous Peoples, Postcolonialism and International Law: the ILO Regime (1919-1989). Oxford: Oxford University Press, 410 pp.

Rodríguez-Piñero, Luis (2013): “La sentencia de la Corte Interamericana”. En Gómez IsA, Felipe (ed.): El caso Awas Tingni. Derechos humanos entre lo local y lo global. Bilbao: Publicaciones de la Universidad de Deusto, pp. 123-38.

Ruiz Chiriboga, Oswaldo (2006). "El derecho a la identidad cultural de los pueblos indígenas y las minorías nacionales: una mirada desde el sistema interamericano". Sur - Revista Internacional de Derechos Humanos, Vol. 5, pp. 42-69.

Ruiz Chiriboga, Oswaldo, y Donoso, Gina (2014): "Pueblos indígenas y la Corte Interamericana de Derechos Humanos. Fondo y reparaciones". En Steiner, Christian, y Uribe, Patricia (eds.): Convención Americana sobre Derechos Humanos: comentario, La Paz: Fundación Konrad Adenauer, pp. 947-1026.

Shahabuddeen, Mohamed (2007): Precedent in the World Court. Nueva York: Cambridge University Press, 268 pp. 
Salacuse, Jeswald (2010): The Law of International Investment Treaties. Oxford: Oxford University Press, 517 pp.

Salmón, Elizabeth (2011): Jurisprudencia de la Corte Interamericana de Derechos Humanos. Bogotá: Editorial Universidad del Rosario, 257 pp.

Sarmiento, Andrés (2015). "Case of Indigenous Communities Kuna of Madungandí and Emberá of Bayano and its Members v. Panama”. International Law - Revista Colombiana de Derecho Internacional, Vol. 27, pp. 9-38.

Schettini, Andrea (2012). "Por un nuevo paradigma de protección de los derechos de los pueblos indígenas: un análisis crítico de los parámetros establecidos por la Corte Interamericana de Derechos Humanos". Sur - Revista Internacional de Derechos Humanos, Vol. 17, pp. 65-87.

Shany, Yuval (2009). "No Longer a Weak Department of Power? Reflections on the Emergence of a New International Judiciary". European Journal of International Law, Vol. $20 \mathrm{~N}^{\circ}$ 1, pp. 73-91.

Sieder, Rachel (2011): "Pueblos indígenas y derecho(s) en América Latina”. En Rodríguez Garavito, César (ed.), El derecho en América Latina: un mapa para el pensamiento juridico del siglo XXI. Buenos Aires: Siglo Veintiuno Editores, pp. 303-21.

Swepston, Lee (1990). "A New Step in the International Law on Indigenous and Tribal Peoples: the ILO Convention No. 169 of 1989". Oklahoma City University Law Review, Vol. 15 N³, pp. 677714.

Thirlway, Hugh (2014): The Sources of International Law. Nueva York: Oxford University Press, 239 pp.

Thornberry, Patrick (2002): Indigenous Peoples and Human Rights. Manchester: Manchester University Press, 484 pp.

UN Permanent Forum on Indigenous Peoples (2009): State of the World's Indigenous Peoples. Nueva York: Publicaciones de la ONU, 238 pp.

van Dijk, P., et al. (eds.) (2006): Theory and Practice of the European Convention on Human Rights. Mortsel: Intersentia Publishers, 1190 pp.

VENZKe, Ingo (2014): How Interpretation Makes International Law: On Semantic Change And Normative Twists. Oxford: Oxford University Press, 344 pp.

VenzKe, Ingo (2012). "Role of International Courts as Interpreters and Developers of the Law: Working out the Jurisgenerative Practice of Interpretation". Loyola of Los Angeles International and Comparative Law Review, Vol. $34 \mathrm{~N}^{\circ}$ 1, pp. 99-131. 
von Bogdandy, Armin y Venzke, Ingo (2011). "Beyond Dispute: International Judicial Institutions as Lawmakers". German Law Journal, Vol. $12 \mathrm{~N}^{\circ}$ 5, pp. 979-1003.

Vuotтo, Jonathan (2004). "Awas Tingni v. Nicaragua: International Precedent for Indigenous Land Rights". Boston University International Law Journal, Vol. 22 No 22, pp. 219-43.

Weckel, Philippe, y Rinaldi, Karine (2008): "Relativisme culturel ou universalité des droits de l'homme? La réponse donnée par la Cour Interaméricaine des Droits de l'Homme par la prise en compte des coutumes indiennes". En Société Française pour le Droit InTERnational (ed.): Droit international et diversité des cultures juridiques / International Law and Diversity of Legal Cultures. París: Editions A. Pedone, pp. 421-31.

Wiessner, Siegfried (2008). "Indigenous Sovereignty: A Reassessment in Light of the UN Declaration on the Rights of Indigenous People". Vanderbilt Journal of Transnational Law, Vol. $41 \mathrm{~N}^{\circ}$ 4, pp. 1141-76.

Wiessner, Siegfried (1999). "Rights and Status of Indigenous Peoples: A Global International and Comparative Legal Analysis”. Harvard Human Rights Journal, Vol. 12, pp. 57-128.

White, Robin, y Ovey, Clare (2010): Jacobs, White and Ovey: The European Convention on Human Rights. Oxford: Oxford University Press, $720 \mathrm{pp}$.

Xanthaki, Alexandra (2010): Indigenous Rights and United Nations Standards: Self-determination, Culture and Land. Nueva York: Cambridge University Press, 314 pp.

Xanthaki, Alexandra (2009). "Indigenous Rights in International Law over the Last 10 Years and Future Developments". Melbourne Journal of International Law, Vol. $10 \mathrm{~N}^{\circ} 1$, pp. 27-37.

Yupsanis, Athanasios (2010). "ILO Convention No. 169 Concerning Indigenous and Tribal Peoples in Independent Countries 1989-2009: An Overview". Nordic Journal of International Law, Vol. $79 \mathrm{~N}^{\circ} 3$, pp. 433-56.

Zalaquett, José (2008). "La Declaración de Naciones Unidas sobre Derechos de los Pueblos Indígenas“. Anuario de Derechos Humanos, 4, pp. 139-48.

\section{INSTRUMENTOS CITADOS}

Estatuto de la Corte Internacional de Justicia de 1945

Declaración Americana de Derechos y Deberes del Hombre de 1948

Convenio Europeo para la Protección de los Derechos Humanos y de las Libertades Fundamentales de 1950 
Protocolo Adicional al Convenio para la Protección de los Derechos Humanos y de las Libertades Fundamentales de 1952

Convenio N 107 de la OIT de 1957, sobre Pueblos Indígenas y Tribales

Convención Internacional sobre la Eliminación de todas las Formas de Discriminación Racial de 1965

Pacto Internacional de Derechos Civiles y Políticos de la ONU de 1966

Pacto Internacional de Derechos Económicos, Sociales y Culturales de la ONU de 1966

Convención Americana sobre Derechos Humanos de 1969

Convención de Viena sobre el Derecho de los Tratados de 1969

Convenio No 169 de la OIT de 1989, sobre Pueblos Indígenas y Tribales en Países Independientes

Declaración de Río sobre el Medio Ambiente y el Desarrollo de 1992

Proyecto de Declaración Americana sobre los Derechos de los Pueblos Indígenas de la OEA de 1997

Declaración de la ONU sobre los Derechos de los Pueblos Indígenas de 2007

Principios Rectores de la ONU sobre las Empresas y los Derechos Humanos del 2011

\section{JURISPRUDENCIA CITADA}

Corte Interamericana de Derechos Humanos. 1 de febrero de 2000. Serie C No. 66 (excepciones preliminares). "Comunidad Mayagna (Sumo) Awas Tingni c. Nicaragua”.

Corte Europea de Derechos Humanos. 18 de enero de 2001 (sentencia). "Sally Chapman c. Reino Unido".

Corte Interamericana de Derechos Humanos. 6 de febrero de 2001. Serie C No. 74 (sentencia). "Baruch Ivcher Bronstein c. Perú”.

Corte Interamericana de Derechos Humanos. 31 de agosto de 2001. Serie C No. 79 (sentencia '). "Comunidad Mayagna (Sumo) Awas Tingni c. Nicaragua”.

Corte Interamericana de Derechos Humanos. 31 de agosto de 2001. Serie C No. 79 (voto concurrente del juez García Ramírez). "Comunidad Mayagna (Sumo) Awas Tingni c. Nicaragua".

Corte Interamericana de Derechos Humanos. 28 de febrero de 2003. Serie C No. 98 (sentencia). “Cinco Pensionistas c. Perú”.

Corte Europea de Derechos Humanos. 17 de febrero de 2004 (sentencia). "Jerzy Gorzelik y Otros c. Polonia”.

Corte Interamericana de Derechos Humanos. 29 de abril de 2004. Serie C No. 105 (sentencia). "Masacre Plan de Sánchez c. Guatemala”. 
Corte Europea de Derechos Humanos. 27 de mayo de 2004 (sentencia). "James Connors c. Reino Unido".

Corte Interamericana de Derechos Humanos. 7 de septiembre de 2004. Serie C No. 114 (sentencia). "Daniel Tibi c. Ecuador”.

Corte Interamericana de Derechos Humanos. 19 de noviembre 2004. Serie C No. 116 (sentencia). "Masacre Plan de Sánchez c. Guatemala”.

Corte Interamericana de Derechos Humanos. 15 de junio de 2005. Serie C No. 124 (sentencia). "Comunidad Moiwana c. Surinam".

Corte Interamericana de Derechos Humanos. 17 de junio de 2005.

Serie C No. 125 (sentencia). "Comunidad Indígena Yakye Axa c. Paraguay".

Corte Interamericana de Derechos Humanos. 17 de junio de 2005.

Serie C No. 125 (voto parcialmente disidente del juez Abreu).

"Comunidad Indígena Yakye Axa c. Paraguay".

Corte Interamericana de Derechos Humanos. 22 de noviembre de 2005. Serie C No. 135 (sentencia). "Humberto Palamara Iribarne c. Chile".

Corte Interamericana de Derechos Humanos. 6 de febrero de 2006.

Serie C No. 142 (interpretación). "Comunidad Indígena Yakye Axa c. Paraguay".

Corte Interamericana de Derechos Humanos. 29 de marzo de 2006. Serie C No. 146 (sentencia). "Comunidad Indígena Sawhoyamaxa c. Paraguay".

Corte Interamericana de Derechos Humanos. 29 de marzo de 2006. Serie C No. 146 (voto razonado del juez García Ramírez). "Comunidad Indígena Sawhoyamaxa c. Paraguay".

Corte Interamericana de Derechos Humanos. 1 de junio de 2006. Serie C No. 148 (sentencia). "Masacres de Ituango c. Colombia”.

Corte Interamericana de Derechos Humanos. 28 de noviembre de 2007. Serie C No. 172 (sentencia). "Pueblo Saramaka c. Surinam”.

Corte Interamericana de Derechos Humanos. 6 de mayo de 2008.

Serie C No. 179 (sentencia). "María y Julio Guillermo Salvador Chiriboga c. Ecuador".

Corte Interamericana de Derechos Humanos. 6 de mayo de 2008.

Serie C No. 179 (voto concurrente del juez Ventura). "María y Julio Guillermo Salvador Chiriboga c. Ecuador”.

Corte Interamericana de Derechos Humanos. 12 de agosto de 2008. Serie C No. 185 (interpretación). "Pueblo Saramaka c. Surinam".

Corte Interamericana de Derechos Humanos. 26 de noviembre de 2008. Serie C No. 189 (sentencia). "Juan Carlos Chaparro Álvarez y Freddy Hernán Lapo Íniguez c. Ecuador”. 
Corte Interamericana de Derechos Humanos. 1 de julio de 2009. Serie C No. 198 (sentencia). "Alejandro Acevedo Buendía y Otros (Cesantes y Jubilados de la Contraloría) c. Perú".

Corte Interamericana de Derechos Humanos. 24 de agosto de 2010. Serie C No. 214 (sentencia). "Comunidad Indígena Xákmok Kásek c. Paraguay".

Corte Interamericana de Derechos Humanos. 24 de agosto de 2010. Serie C No. 214 (voto concurrente del juez Vio Grossi). "Comunidad Indígena Xákmok Kásek c. Paraguay".

Corte Interamericana de Derechos Humanos. 4 de marzo de 2011. Serie C No. 223 (sentencia). "Víctor Abrill Alosilla y Otros c. Perú".

Corte Interamericana de Derechos Humanos. 24 de noviembre de 2011. Serie C No. 237 (sentencia). "Familia Barrios c. Venezuela".

Corte Interamericana de Derechos Humanos. 27 de junio de 2012. Serie C No. 245 (sentencia). "Pueblo Indígena Kichwa de Sarayaku c. Ecuador".

Corte Interamericana de Derechos Humanos. 31 de agosto de 2012. Serie C No. 246 (sentencia). "Sebastián Furlan y Familiares c. Argentina”.

Corte Interamericana de Derechos Humanos. 25 de octubre de 2012. Serie C No. 252 (sentencia). "Masacres de El Mozote y Lugares Aledańos c. El Salvador”.

Corte Interamericana de Derechos Humanos. 30 de noviembre de 2012. Serie C No. 263 (sentencia). "Masacre de Santo Domingo c. Colombia”.

Corte Interamericana de Derechos Humanos. 22 de agosto de 2013. Serie C No. 265 (sentencia). "Carlos y Pablo Mémoli c. Argentina".

Corte Interamericana de Derechos Humanos. 20 de noviembre de 2013. Serie C No. 270 (sentencia). "Comunidades Afrodescendientes Desplazadas de la Cuenca del Río Cacarica (Operación Génesis) c. Colombia”.

Corte Interamericana de Derechos Humanos. 30 de enero de 2014. Serie C No. 276 (voto concurrente del juez Ferrer Mac-Gregor). "Liakat Ali Alibux c. Surinam".

Corte Interamericana de Derechos Humanos. 29 de mayo de 2014. Serie C No. 279 (sentencia). "Segundo Norín Catrimán y otros (Dirigentes, miembros y activistas del pueblo indígena Mapuche) $\mathrm{c}$. Chile".

Corte Interamericana de Derechos Humanos. 14 de octubre de 2014. Serie C No. 284 (sentencia). "Pueblos Indígenas Kuna de Madungandí y Emberá de Bayano y sus miembros c. Panamá”.

Corte Interamericana de Derechos Humanos. 14 de octubre de 2014. Serie C No. 284 (voto parcialmente disidente del juez Ferrer 
Mac-Gregor). "Pueblos Indígenas Kuna de Madungandí y Emberá de Bayano y sus miembros c. Panamá".

Corte Interamericana de Derechos Humanos. 1 de septiembre de 2015. Serie C No. 299 (sentencia). "Comunidad Campesina de Santa Bárbara c. Perú".

Corte Interamericana de Derechos Humanos. 8 de octubre de 2015. Serie C No. 304 (sentencia). "Comunidad Garífuna de Punta Piedra y sus miembros c. Honduras".

Corte Interamericana de Derechos Humanos. 8 de octubre de 2015. Serie C No. 305 (sentencia). "Comunidad Garífuna Triunfo de la Cruz y sus miembros c. Honduras".

Corte Interamericana de Derechos Humanos. 8 de octubre de 2015. Serie C No. 305 (voto concurrente del juez Sierra Porto). "Comunidad Garífuna Triunfo de la Cruz y sus miembros c. Honduras".

Corte Interamericana de Derechos Humanos. 25 de noviembre de 2015. Serie C No. 309 (sentencia). "Pueblos Kaliña y Lokono c. Surinam".

Corte Interamericana de Derechos Humanos. 25 de noviembre de 2015. Serie C No. 309 (voto concurrente conjunto de los jueces Sierra Porto y Ferrer Mac-Gregor). "Pueblos Kalińa y Lokono c. Surinam". 